\title{
Sources of uncertainties in modelling black carbon at the global scale
}

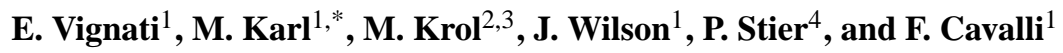 \\ ${ }^{1}$ European Commission, Joint Research Centre, Institute for Environment and Sustainability, Ispra, Italy \\ ${ }^{2}$ Netherlands Institute for Space Research (SRON), Utrecht, The Netherlands \\ ${ }^{3}$ Wageningen University and Research Centre, Wageningen, The Netherlands \\ ${ }^{4}$ Atmospheric, Oceanic and Planetary Physics, Department of Physics, University of Oxford, Oxford, UK \\ *now at: Norwegian Institute for Air Research, Kjeller, Norway
}

Received: 4 November 2009 - Published in Atmos. Chem. Phys. Discuss.: 16 November 2009

Revised: 22 February 2010 - Accepted: 23 February 2010 - Published: 16 March 2010

\begin{abstract}
Our understanding of the global black carbon (BC) cycle is essentially qualitative due to uncertainties in our knowledge of its properties. This work investigates two source of uncertainties in modelling black carbon: those due to the use of different schemes for $\mathrm{BC}$ ageing and its removal rate in the global Transport-Chemistry model TM5 and those due to the uncertainties in the definition and quantification of the observations, which propagate through to both the emission inventories, and the measurements used for the model evaluation.
\end{abstract}

The schemes for the atmospheric processing of black carbon that have been tested with the model are (i) a simple approach considering $\mathrm{BC}$ as bulk aerosol and a simple treatment of the removal with fixed $70 \%$ of in-cloud black carbon concentrations scavenged by clouds and removed when rain is present and (ii) a more complete description of microphysical ageing within an aerosol dynamics model, where removal is coupled to the microphysical properties of the aerosol, which results in a global average of $40 \%$ in-cloud black carbon that is scavenged in clouds and subsequently removed by rain, thus resulting in a longer atmospheric lifetime. This difference is reflected in comparisons between both sets of modelled results and the measurements. Close to the sources, both anthropogenic and vegetation fire source regions, the model results do not differ significantly, indicating that the emissions are the prevailing mechanism determining the concentrations and the choice of the aerosol scheme does not influence the levels. In more remote areas such as

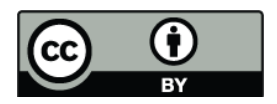

Correspondence to: E. Vignati (elisabetta.vignati@jrc.ec.europa.eu) oceanic and polar regions the differences can be orders of magnitude, due to the differences between the two schemes. The more complete description reproduces the seasonal trend of the black carbon observations in those areas, although not always the magnitude of the signal, while the more simplified approach underestimates black carbon concentrations by orders of magnitude.

The sensitivity to wet scavenging has been tested by varying in-cloud and below-cloud removal. BC lifetime increases by $10 \%$ when large scale and convective scale precipitation removal efficiency are reduced by $30 \%$, while the variation is very small when below-cloud scavenging is zero.

Since the emission inventories are representative of elemental carbon-like substance, the model output should be compared to elemental carbon measurements and if known, the ratio of black carbon to elemental carbon mass should be taken into account when the model is compared with black carbon observations.

\section{Introduction}

Black carbon (BC) is a product of incomplete combustion of carbonaceous matter (fossil fuel, biomass and biofuels) that has an impact on both air quality and climate. Atmospheric particles affect the climate both directly by intercepting incoming solar radiation and scattering a portion back to space and absorbing a fraction, heating the local atmosphere and indirectly by changing cloud albedo and lifetimes. The present best estimate of the net climate forcing by anthropogenic particles is about $-1.2 \mathrm{~W} / \mathrm{m}^{2}$ (IPCC, 2007), not including aerosol lifetime effects, compared with

Published by Copernicus Publications on behalf of the European Geosciences Union. 
the climate forcing by the anthropogenic $\mathrm{CO}_{2}$ of $+1.6 \mathrm{~W} / \mathrm{m}^{2}$, however, the uncertainty in the estimate of the aerosol forcing is much larger. Black carbon is the principal light absorbing component of atmospheric particles that heat the atmosphere. Locally the sign of the radiative effect of this heating depends upon the underlying surface albedo, but globally black carbon is estimated to cause a radiative forcing of $0.20 \pm 0.15 \mathrm{~W} / \mathrm{m}^{2}$ (IPCC, 2007); furthermore Stier et al. (2007) has demonstrated the strong sensitivity of the topof-atmosphere aerosol radiative forcing to $\mathrm{BC}$ absorption. When deposited on snow, black carbon containing aerosol particles reduce the albedo, thereby enhancing heating of the snow and causing a more rapid melting, which in turn can lead to an even larger albedo change.

To assess the impact of black carbon at the global scale Chemistry Transport Models and General Circulation Models are used even though the resulting studies contain large uncertainties due to both the black carbon emissions and the treatment of physical and chemical processes affecting black carbon (Cooke and Wilson, 1996; Liousse et al., 1996; Jacobson, 2002; Chung and Seinfeld, 2002; Stier et al., 2005; Koch and Hansen, 2005; Reddy and Boucher, 2007; Koch et al., 2007; Stier et al., 2007). To evaluate the effect of future emission reductions these uncertainties in the atmospheric black carbon cycle need to be better understood and quantified.

It is not always clear what is meant by "black carbon" in models. Primary carbonaceous particles that are the product of the fuel combustion, often called soot, consist of a mixture of elemental and organic carbon; while other elements such as oxygen, hydrogen and nitrogen are also frequently present in the structure (Seinfeld and Pandis, 1998; Bond and Bergstrom, 2006). The chemical and physical properties of these primary aerosol particles evolve when transported in the atmosphere due to a number of competing processes such as condensation, absorption and coagulation as well as surface reactions, whereby the primary part becomes increasingly imbedded in other organic and inorganic components changing light absorption and refractory properties of the particles. Diverse measurement methods have been developed and utilized for the quantification of this aerosol component on a routine basis making use of some characteristic properties of soot particles. These methods have created new operational definitions such as black carbon and elemental carbon (EC) depending whether they respectively take advantage of the light absorbing or refractory properties, (i.e. the resistance to the exposure to high temperatures without reacting). Dozens of inter-laboratory comparison studies have been conducted and $\mathrm{BC}$ and $\mathrm{EC}$ concentrations are found to differ considerably, up to a factor 7 among different methods, reducing to a factor of 2-3 among optical methods and a factor of 4 among thermal methods (Chow et al., 2001; Schmid et al., 2001; Currie et al., 2002; Jeong et al., 2004; ten Brink et al., 2004; Watson et al., 2005; Hitzenberger et al., 2006; Reisinger et al., 2008).
However given that the chemical composition of soot particles is not uniform, while the physical properties of the particles are neither constant nor conserved during the lifetime of individual particles, neither of these methods can provide consistently accurate measures of soot and both elemental and black carbon can only be regarded as proxies for its concentration. Regrettably however, these discrepancies are usually disregarded in the modelling studies and the terms elemental carbon and black carbon are used interchangeably as synonyms of soot. Only in a few cases have the differences between the parameters been considered in model evaluations (Schaap et al., 2004; Tsigaridis and Kanakidou, 2003). Of the three, the term black carbon is the one most commonly used in the climate modeling community for soot/black carbon/elemental carbon, as it derives from the optical property, which is that relevant for climate. In the following, we also use the name black carbon for this "substance" that is emitted, transported and transformed in the model studies, however when comparing with observations, we also use the appropriate operational name for the observations themselves (BC for optical and EC for thermo-optical measurements, respectively).

When BC is emitted it undergoes chemical and physical transformations, which are commonly referred to as "ageing". The ageing process results in an overall shift from a more hydrophobic to a more hydrophilic state. The processes contibuting to the ageing are condensation of soluble material on BC particles (Weingartner et al., 1997), coagulation with soluble particles (Fassi-Fihri et al., 1997; Ström et al., 1992) and oxidation (e.g. by $\mathrm{O}_{3}$, see Pöschl et al., 2001) of organic material that coats the particles. The ageing by $\mathrm{O}_{3}$ is a slow process compared to the ageing due to the aerosol dynamics (Croft et al., 2005).

Apart from the fact that these processes are not yet fully known, their explicit numerical treatment is time consuming in large-scale models. The time-scale of the conversion from the hydrophobic to the hydrophilic state affects the BC lifetime, by enabling more efficient removal by wet and dry deposition. The conversion depends on the initial state of the $\mathrm{BC}$, as well as on the presence of other particles and gases in the atmosphere and it is not constant in space and time: the conversion time scale remains uncertain. Some models assume that this conversion can be approximated by an exponential decay process with fixed half-life, called the "ageing time" (e.g. Cooke and Wilson, 1996 proposed 1.15 days). Independently of how the ageing is described assumptions are always required, such as how much soluble material needs to be added to a hydrophobic core "to define" a particle as hydrophilic and thus capable of being taken up into clouds and wet deposited. This adds uncertainty to the model estimates (Wilson et al., 2001; Croft et al., 2005).

Another important uncertainty is in the emission inventories of $\mathrm{BC}$, which show large differences in global emission estimates due to differences in emission factors and/or activity data both for fossil fuel $(4.7-8 \mathrm{TgC} / \mathrm{yr})$ and biomass 
burning (3.6-6 TgC/yr) (Bond et al., 2004; van der Werf, 2004; Cooke et Wilson, 1996; Liousse et al., 1996; Penner et al., 1993; Junker and Liousse, 2008). The quality of the inventories cannot easily be checked by models, since the resulting concentrations are highly model dependent, but are estimated conservatively to have an uncertainty of a factor of two (Bond et al., 2004).

The first attempts to model aerosols in global models used simple mass based models and assumed external mixtures of components and constant size distributions (e.g. Haywood and Shine, 1995; Tegen et al., 1997). Subsequently more elaborate approaches were developed including size resolved descriptions and the inclusion of aerosol dynamics, with the consequent improved descriptions of the aerosol optical properties, of their interactions with clouds, and of the nonlinearities of the aerosol system (Jacobson, 2001; Gong et al., 2003; Wilson et al., 2001; Stier et al., 2005; Stier et al., 2006; Spracklen et al., 2007; Guillaume et al., 2007). Size resolved aerosols and a more explicit treatment of atmospheric processes involving BC may not be important in certain conditions or areas, where other processes determine the concentrations, e.g. close to the source regions. In these regions, simplified descriptions can be sufficiently accurate for certain applications.

Thus, models of the atmospheric black carbon cycle are highly uncertain, consequently the results are difficult to evaluate as they are influenced by: emission inventories that can have an uncertainty of a factor of 2 (Bond et al., 2004); the inclusion of black carbon ageing processes that can change BC lifetime by an order of magnitude (Croft et al., 2005); and finally by wet deposition that is perhaps the most uncertain process in the models (Textor et al., 2006).

The purpose of this study is to investigate important sources of uncertainties in the global BC estimates, by examining firstly the effect of using two different approaches to represent $\mathrm{BC}$ (bulk versus size resolved, dynamics versus more simplified approach to $\mathrm{BC}$ ageing) in the global Transport-Chemistry model TM5 (Krol et al., 2005), then by looking at the impact of the wet removal on BC properties and finally by analysing the consequences of the unclear BC definition and subsequent quantification, information which is used in both the emission inventories, through the emission factors and in measurements used for the model evaluation.

\section{Methodology}

In this study the Transport-Chemistry Model TM5 is used for the evaluation of uncertainties related to $\mathrm{BC}$ processing parameterisations. The model is briefly described in the following section. The second section gives an overview of the emission inventories used in the simulation, while the last section introduces the dataset used in the model evaluation.

\subsection{The Chemistry-Mransport Model TM5}

\subsubsection{Model set-up}

The TM5 model is an off-line global transport chemistry model (Krol et al., 2005) that uses the ECMWF ERA-40 meteorological data. It has a spatial global resolution of $6^{\circ} \times 4^{\circ}$ and a two-way zooming algorithm that allows regions (e.g. Europe, N. America, Africa, and Asia) to be resolved at a finer resolution of $1^{\circ} \times 1^{\circ}$. To smooth the transition between the global $6^{\circ} \times 4^{\circ}$ region and the regional $1^{\circ} \times 1^{\circ}$ domain, a domain with a $3^{\circ} \times 2^{\circ}$ resolution has been added. In the present application the zoom is over Europe, therefore outside the European domain the resolution of the model is $6^{\circ} \times 4^{\circ}$. In the current version, the model has a vertical resolution of 25 layers, defined in a hybrid sigma-pressure coordinate system with a higher resolution in the boundary layer and around the tropopause. The height of the first layer is approximately $50 \mathrm{~m}$.

TM5 uses the slope scheme for the advection calculations (Russell et al., 1981; Petersen et al., 1998). The model transport has been extensively validated using ${ }^{222} \mathrm{Rn}$ and $\mathrm{SF}_{6}(\mathrm{Pe}$ ters et al., 2004; Krol et al., 2005) and further validation was performed within the EVERGREEN Project (Bergamaschi et al., 2006).

Gas phase chemistry is calculated using the CBM-IV chemical mechanism (Gery et al., 1989a, b) modified by Howeling et al. (1998), solved by means of the EBI method (Hertel et al., 1993). Dry deposition is calculated using the ECMWF surface characteristics and the resistance method (Ganzeveld and Lelieveld, 1995).

Wet deposition is the dominant removal process for most aerosols and therefore is a major source of uncertainty in aerosol modelling (Textor et al., 2006). Removal occurs in convective systems (convective precipitation) and in largescale stratiform systems that are associated with weather fronts. The in-cloud removal rates, which depend on the precipitation rate are differentiated for convective and stratiform precipitation and are calculated following Guelle et al. (1998) and Jueken at al. (2001). Aerosol below-cloud scavenging is parameterised according to Dana and Hales (1976). Wet removal is describe in more detail in Appendix A.

\subsubsection{Aerosol description and processes}

TM5 has been run with two different schemes for the aerosols.

In the first set-up, common for bulk models, (hereafter called BULK) only the masses of the aerosol compounds are considered. The inorganic compounds, sulphate, nitrate and ammonium, are internally mixed, while organic carbon, sea salt and dust are externally mixed. Black carbon is also assumed to be externally mixed and resides in the accumulation mode with a mass mean radius of $0.14 \mu \mathrm{m}$ for wet and dry removal. BC is considered hydrophobic and it does not uptake 
Table 1. Boundaries (dry radii, $r$ ), standard deviations $(\sigma)$, particle number $(N)$ and mass $(M)$ tracers of the modes in M7.

\begin{tabular}{lll}
\hline Mode & Soluble/Mixed & Insoluble \\
\hline $\begin{array}{l}\text { Nucleation } \\
r \leq 0.005 \mu \mathrm{m}, \sigma=1.59\end{array}$ & $N_{\text {nuc }}, M_{\mathrm{SO}_{4}}$ & \\
$\begin{array}{l}\text { Aitken } \\
0.005<r \leq 0.05 \mu \mathrm{m}, \sigma=1.59\end{array}$ & $N_{\text {aits }}, M_{\mathrm{SO}_{4}}, M_{\mathrm{BC}}, M_{\mathrm{OC}}$ & $N_{\text {aiti }}, M_{\mathrm{BC}}, M_{\mathrm{OC}}$ \\
$\begin{array}{l}\text { Accumulation } \\
0.05<r \leq 0.5 \mu \mathrm{m}, \sigma=1.59\end{array}$ & $N_{\mathrm{accs}}, M_{\mathrm{SO}_{4}}, M_{\mathrm{BC}}, M_{\mathrm{OC}}, M_{\mathrm{SS}}, M_{\mathrm{DU}}$ & $N_{\mathrm{acci}}, M_{\mathrm{DU}}$ \\
$\begin{array}{l}\text { Coarse } \\
r \geq 0.5 \mu \mathrm{m}, \sigma=2.0\end{array}$ & $N_{\text {coas }}, M_{\mathrm{SO}_{4}}, M_{\mathrm{BC}}, M_{\mathrm{OC}}, M_{\mathrm{SS}}, M_{\mathrm{DU}}$ & $N_{\text {coai }}, M_{\mathrm{DU}}$ \\
\hline
\end{tabular}

water. With large-scale stratiform precipitation a constant interstitial mass fraction is assumed (in the in-cloud removal rate $L_{\text {in }}$ in Appendix A) and the remainder is assumed to be encorporated in cloud droplets and scavenged with the same efficiency as sulphate (Jeuken at al., 2001). In other words a fixed fraction of $\mathrm{BC}$ mass is scavenged depending only on the amount of rainfall and not on the $\mathrm{BC}$ hydrophobic properties. For convective wet removal all $\mathrm{BC}$ mass is scavenged. The fraction of the $\mathrm{BC}$ that is not activated and remains interstitial is highly uncertain and poorly quantified by experiments (Kasper-Giebl et al., 2000; Hitzenberger et al., 1999). In the default TM5 set-up it is assumed that $30 \%$ of the mass remains interstitial. With this set-up the model has been evaluated in model inter-comparison exercises (Textor et al., 2006), and using in-situ, satellite and sun-photometer measurements (De Meji et al., 2006). In the bulk approach BC is assumed not to experience any changes in the hygroscopic properties due to ageing. Aerosol below-cloud scavenging is parameterised accordingly to Dana and Hales (1976) assuming that the mean mass radius is $0.14 \mu \mathrm{m}$.

In the second set-up (DYNA) TM5 is coupled to the microphysical aerosol model M7 (Vignati et al., 2004, 2010) that allows the resolution of particle masses and numbers. The particles are represented by seven internally mixed classes, using a "pseudo-modal" approach. Four classes are for soluble mixed particles representing nucleation, Aitken, accumulation, and coarse mode, and three are for the insoluble (Aitken, accumulation, and coarse mode). The structure, boundaries and chemical composition of the modes are reported in Table 1. Nucleation, condensation of sulphuric acid and coagulation between the particles are included. BC can be present in the insoluble and soluble Aitken modes, and in the soluble accumulation and coarse modes. The ageing is accomplished by considering condensation of $\mathrm{H}_{2} \mathrm{SO}_{4}$ and coagulation with soluble particles, which form a soluble shell around the hydrophobic core and the particles are moved from the insoluble to the soluble/mixed modes. The other components in M7 are mineral dust, primary organic carbon (OC), sulfate, and sea salt. As for the BULK approach we assume that all particles are removed in case of convective wet removal. In presence of large scale precipitation only the soluble accumulation and coarse modes are scavenged by rain, while the remaining modes (insoluble Aitken, accumulation, coarse and soluble nucleation and Aitken) form interstitial aerosols and they are not removed in cloud. The interstitial aerosol fraction it is not assumed a constant as for BULK varies in time and space. The soluble accumulation and coarse modes are assumed to form cloud droplets where the oxidation of $\mathrm{SO}_{2}$ by $\mathrm{O}_{3}$ and $\mathrm{H}_{2} \mathrm{O}_{2}$ takes place; the resulting sulphate is partitioned between the two modes as function of number of particles present in the modes (Stier at al., 2005). Below cloud scavenging is parameterised by accordingly to Dana and Hales (1976) and the removal is function of the particle mode dimension.

The model simulations have been performed using ECMWF meteorological fields for the years 2002 and 2003, years when the EMEP EC/OC intensive measurement campaign took place.

\subsection{Emission inventories}

The available emission inventories of $\mathrm{BC}$, Particulate Organic Matter (POM) and primary sulphate are for mass only. Some assumptions are therefore required to calculate the emitted number of particles. Sulphuric acid is the only gaseous compounds interacting with the particles though the dynamics therefore details on the sulphur emissions are reported in a following paragraph.

Sea salt is emitted using an on-line emission function following Gong (2003). Dust and the remaining gaseous emission inventories as well as emission heights are from the AEROCOM model inter-comparison exercise (Dentener et al., 2006) (http://nansen.ipsl.jussieu.fr/AEROCOM/). Global emission fields are reported in Table 2.

\subsubsection{BC and POM emissions}

The BC and POM emission inventories used in the present application are from Bond et al. (2004) for the anthropogenic contributions (fossil and bio fuels) and from van der 
Werf (2004) for large scale biomass burning areas. The emission factors used in the $\mathrm{BC}$ anthropogenic emission inventories are predominantly based on thermal-optical measurements and therefore they represent a more EC-like carbonaceous compound rather than $\mathrm{BC}$ ( $\mathrm{T}$. Bond, personal communication, 2008). Similarly biomass burning emission inventories are also based on emission factors (Andreae and Merlet, 2001) derived mostly from thermal-optical techniques.

In both simulations black carbon is assumed to be insoluble when emitted. In the DYNA case the number of $\mathrm{BC}$ and POM emitted particles is calculated assuming the freshly emitted particles ever number median radii of 0.03 and $0.075 \mu \mathrm{m}$, for fossil/bio fuel and biomass burning, respectively, and emitted in the insoluble Aitken mode with standard deviation $\sigma=1.59$ (Stier et al., 2005). $65 \%$ of the emitted POM is considered soluble.

The model does not contain a module for the calculation of Secondary Organic Aerosols (SOA) therefore monthly emission fields of SOA are used following the recommendations of Dentener et al. (2006). A factor of 1.4 is used to convert $\mathrm{OC}$ to POM.

\subsubsection{Sulphur emissions}

Anthropogenic emission inventories from transport, production and industrial processes, and domestic use are from IIASA (Dentener et al., 2005; Cofala et al., 2007). Biomass burning sulphur emissions are from van der Werf (2004), volcanic emissions from Dentener et al. (2006). While $97.5 \%$ of sulphur of anthropogenic sources is emitted as $\mathrm{SO}_{2}, 2.5 \%$ is considered sulphate, to take into account the $\mathrm{SO}_{4}$ production in plumes, as sub-grid process, and emitted in the following modes: $\mathrm{SO}_{4}$ from industrial sources in the accumulation soluble mode (number mean radius of emission $=0.075 \mu \mathrm{m}$ ); sulphate from domestic, transport and biomass burning is emitted $50 \%$ in the Aitken mode with number mean radius $=0.03 \mu \mathrm{m}$ and $50 \%$ in the accumulation mode and number mean radius $=0.075 \mu \mathrm{m}$ (Stier et al., 2005).

DMS fluxes are estimated following the parameterisation proposed by Liss and Merlivat (1986), they are function of the wind speed and temperature and are calculated from DMS sea water concentrations from Kettle et al. (1999).

\subsection{EC and BC datasets used for model evaluation}

Modelled concentrations are compared with an extensive data set of observations distinguished by measurement method, season and region. The dataset contains network measurements of EC: EMEP (Yttri et al., 2007) and IM$\mathrm{PROVE}^{1}$, as well as long-term and campaign measurements of both EC and BC. The long-term measurements were collected at the Arctic stations of Alert (Sharma et al., 2004, 2006: aethalometer) and Barrow (Bodhaine, 1995: aethalometer), in the Amazon basin (Echalar et al., 1998:

\footnotetext{
${ }^{1}$ http://vista.cira.colostate.edu/improve/
}

Table 2. Global annual aerosol $\left(\mathrm{Tg} \mathrm{yr}^{-1}\right)$ emissions (sulphur in $\mathrm{TgS} \mathrm{yr}^{-1}$ ).

\begin{tabular}{llll}
\hline Species & Source & Reference & Emissions \\
\hline POM & Fossil + bio fuels & Bond et al. (2004) & 12.3 \\
& Biomass burning & van der Werf et al. (2004) & 34.7 \\
& SOA & Dentener et al. (2006) & 19.1 \\
BC & Fossil+bio fuels & Bond et al. (2004) & 4.67 \\
& Biomass burning & van der Werf et al. (2004) & 3.04 \\
Sea Salt & Wind driven & Gong (2003) & $6297^{*}$ \\
Dust & Wind driven & Dentener et al. (2006) & 1776 \\
$\mathrm{SO}_{2}$ & Industry, traffic, & Dentener et al. (2005, 2006), & \\
& domestic, biomass & Cofala et al. (2007) & 68.75 \\
& burning, volcanos & & \\
DMS & Marine & Kettle et al. (1999) & $18.46^{*}$ \\
\hline
\end{tabular}

* estimates for the year 2002-2003.

light reflectance technique), and at Halley, Antarctica (Wolff and Cachier, 1998: aethalometer). The observations are chosen as representative of regional background levels to be coherent with the model scale, even though not all the EMEP sites participating in the 2002-2003 campaign have this characteristic. The network measurements were taken in a few samples per week and the model output has been sampled to represent exactly those days and sampling hours. All other measurements, other than EMEP and IMPROVE, were selected only if the collection density was high enough to allow a comparison with monthly modelled averages (this means almost continuous measurements during the month). For the sites where observations are not from the run years (20022003) the model results are averaged over the two year simulations for the corresponding observational periods.

Measurement inter-comparison studies showed that when the same sample is analysed with both optical techniques and thermo-optical analysis the mass of $\mathrm{BC}$ varies from 1 or little less to 3 times the mass of $\mathrm{EC}$, with the higher $\mathrm{BC} / \mathrm{EC}$ ratios found in urban areas (ten Brink, 2004; Jeong et al., 2004). It is therefore important to consider $\mathrm{EC}$ and $\mathrm{BC}$ measurements separately. The measurement sites used are shown and identified in Fig. 1. Most of the EC measurements are made in Europe and in USA, close to anthropogenic sources; whereas the optical observations of $\mathrm{BC}$ are typically found in areas where thermal-optical methods cannot be operated as monitoring techniques.

The modelled black carbon vertical profiles are also compared to aircraft measurements made by Single Particle Soot absorption Photometers (SP2s) (Schwarz et al., 2006; Slowik et al., 2007) onboard NASA and NOAA research aircraft. The campaigns are at tropical and middle latitudes and high latitudes over North America. Observational data and averaging methodology are as in Koch et al. (2009). 


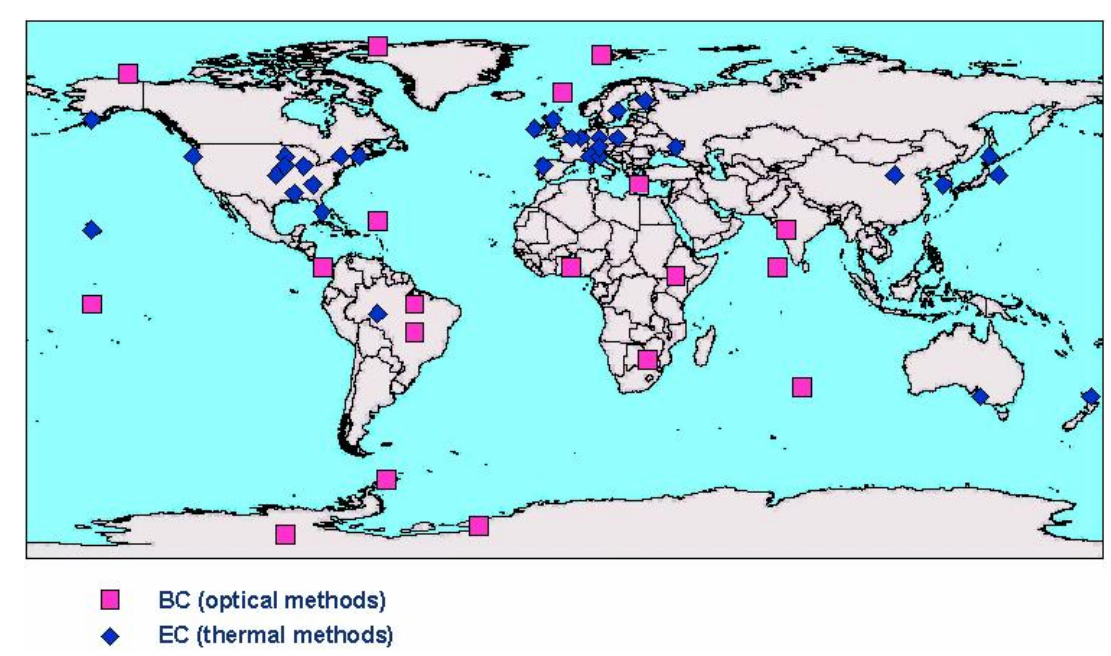

Fig. 1. Map of the measurement sites used for model evaluation.

\section{Results}

\subsection{Burdens and concentrations}

The comparison of surface mean $\mathrm{BC}$ concentrations of the BULK and DYNA cases (Fig. 2) shows similar concentrations and gradients over the source regions (Europe, North and South America, Asia and Africa), while the gradients towards the most remote regions (the Poles and Oceans) are stronger for BULK than in the DYNA case, due to higher scavenging rate during the transport. Inspecting the annual zonal means (Fig. 3) reveals that in TM5-DYNA the transport of $\mathrm{BC}$ to the higher levels of the atmosphere and to remote regions is favoured, while in the BULK case BC remains more confined to the lower atmosphere above the source regions.

Over the continents where emissions are taking place there is still a large percentage of freshly-emitted insoluble black carbon.

The global BC burden reflects the features of the surface concentrations. The burden is lower in the BULK case $(0.11 \mathrm{TgC})$ than the DYNA case $(0.14 \mathrm{TgC})$, corresponding to $\mathrm{BC}$ lifetimes of 4.7 and 6.2 days, respectively. Other global models using different formulations for black carbon processing and emission inventories have reported burdens ranging from $0.11-0.25 \mathrm{TgC}$ and lifetimes of 4-15 days (Liousse et al., 1996; Cooke and Wilson, 1996; Chung and Seinfeld, 2002; Croft et al., 2005; Koch and Hansen, 2005; Stier et al., 2005; Textor et al., 2006, 2007).

TM5 estimates dry and wet deposition around 0.16 and $8 \mathrm{TgC}^{-1}$, respectively, for both approaches; as expected wet deposition is by far the predominant mechanism of removal.

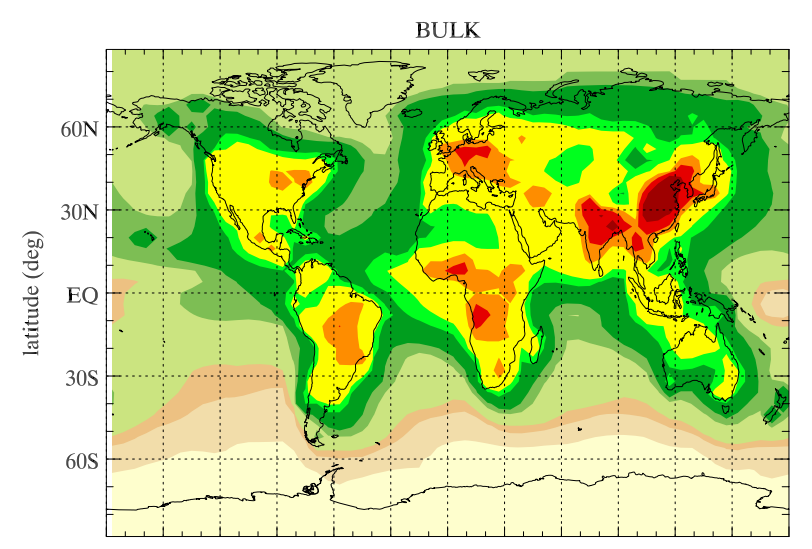

180W 150W 120W 90W 60W 30W 0E 30E 60E 90E 120E 150E 180E longitude (deg)

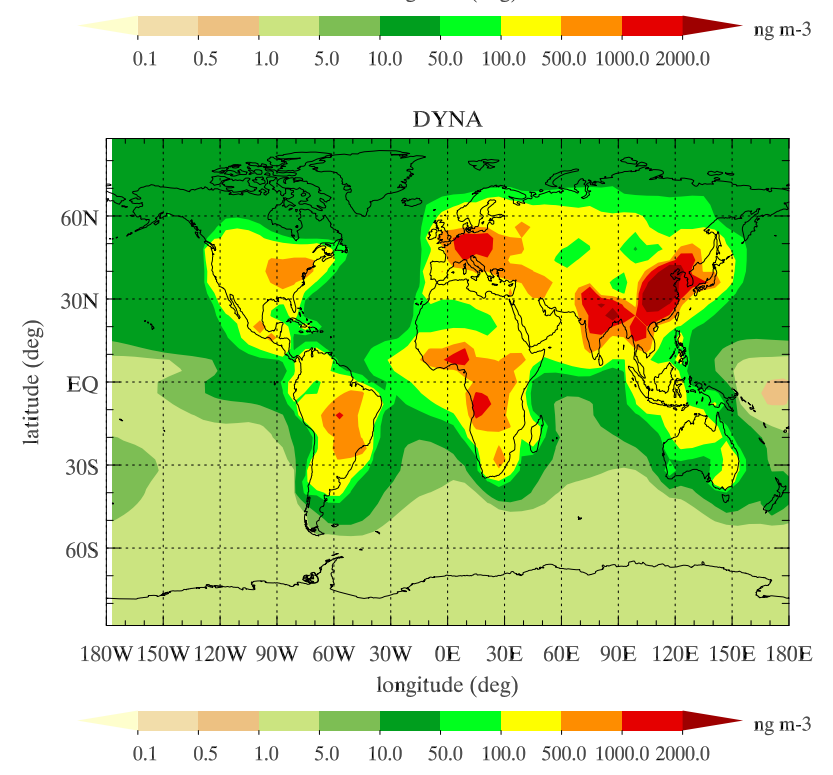

Fig. 2. Annual mean surface layer modelled $B C\left(\mathrm{ng} / \mathrm{m}^{3}\right.$, ambient conditions). 

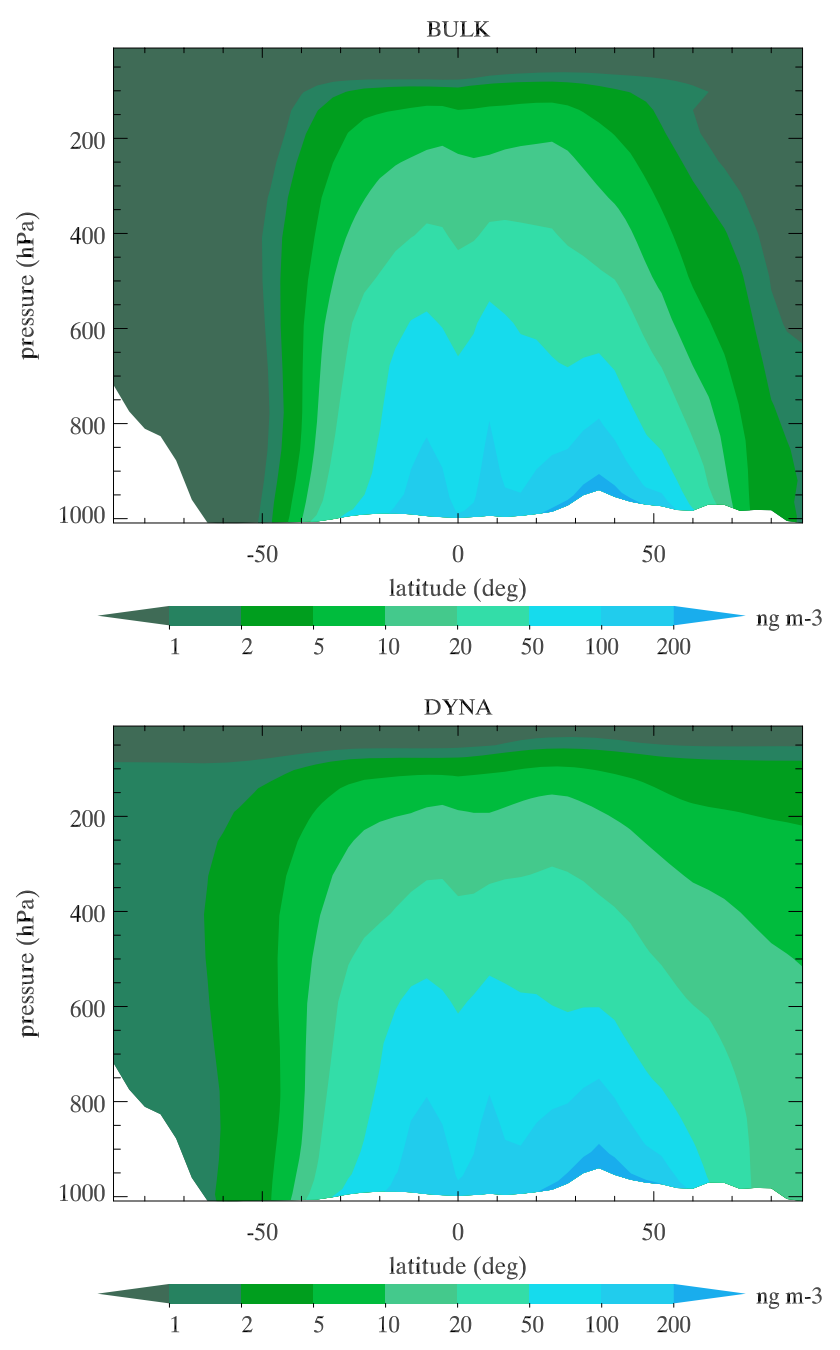

Fig. 3. Annual and zonal mean modelled BC $\left(\mathrm{ng} / \mathrm{m}^{3}\right.$, ambient conditions).

\subsection{Comparison with measurements}

Given that BC can be 1 to 3 times the EC for the same sample and that the emissions used are more characteristic of EC, comparisons with the observations are inevitably qualitative. However it would be reasonable to expect agreement between observed EC and the modelled concentrations and agreement or under-prediction of observed BC concentrations, but by no more than a factor of 3 and less in remote areas.

The scatter-plots of the modelled concentrations versus the EMEP and IMPROVE EC observations are displayed in Fig. 4. The evaluation shows that the two results differ very little among each other, confirming that close to the sources emissions and synoptic scale mixing are the dominant processes influencing the modelled concentrations. Over Europe the model represents better the concentrations (spatial correlation coefficient $R^{2}=0.78$ and 0.79 ) while over United

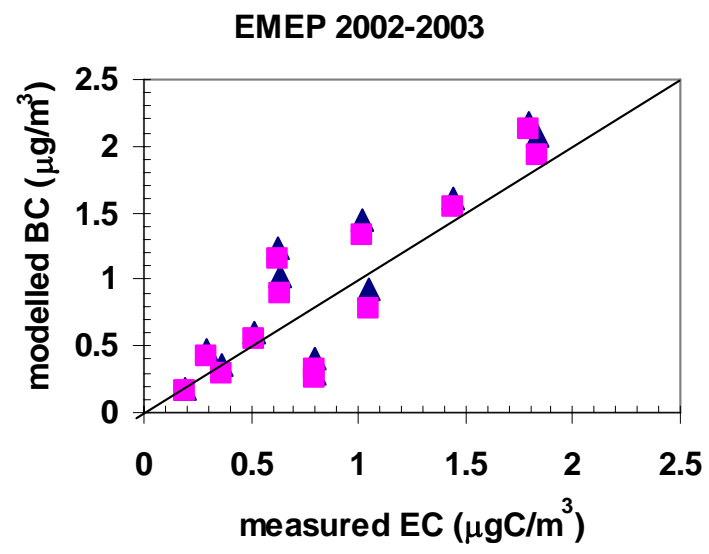

IMPROVE 2002-2003

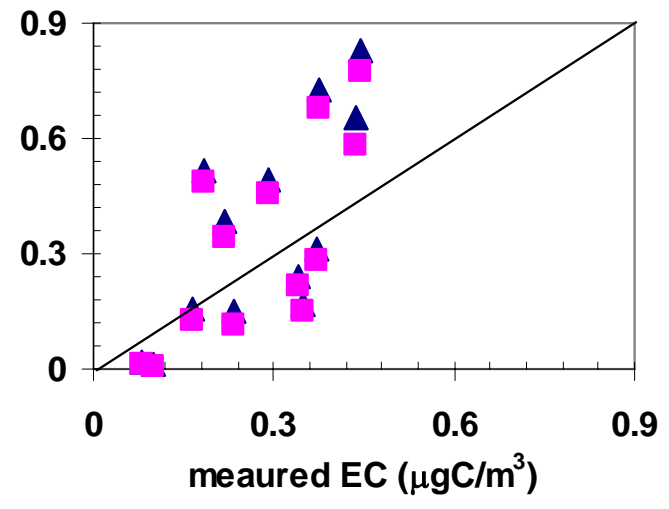

Fig. 4. Scatter-plots of model (squared-TM5-BULK, triangle-TM5DYNA) BC and observed EC concentrations measured by EMEP and IMPROVE networks (ambient conditions).

States the correlation coefficients are lower, 0.49-0.50. The coarser horizontal resolution of the global domain used for North America is probably a factor in the poorer model performance. The emission inventories of Bond et al. (2004) seem to give a good estimate of the anthropogenic emissions over Europe and USA regarding the yearly average EC concentrations, however the correlation coefficients for the temporal correlations of daily averages for the single EMEP and IMPROVE stations are very poor (Tables 3 and 4). We note here that seasonal or diurnal variations in the emissions are not considered, although it has been shown to have a significant impact on aerosol estimates (de Meij et al., 2006).

In Tables 5 and 6 the comparison between modelled BC and measured $\mathrm{EC}$ and $\mathrm{BC}$ respectively for other rural and marine sites is reported. In general at the marine sites the DYNA results give better agreement with the observations. For sites in Asia, Africa and South America (FNS in Table 5 and the last five stations of the Table 6), which are typical biomass burning sites, the model always underestimates the 
Table 3. Daily correlation coefficients for the EMEP stations.

\begin{tabular}{llllllll}
\hline \multicolumn{7}{c}{ Station identifier } \\
\hline \multirow{2}{*}{$R^{2}$} & AT02 & BE05 & CZ03 & DE02 & FI17 & GB46 & IE31 \\
& 0.04 & 0.56 & 0.18 & 0.15 & 0.17 & 0.40 & 0.60 \\
$R^{2}$ & IT04 & IT08 & NL09 & PT01 & SE12 & SK04 & \\
\hline
\end{tabular}

Table 4. Daily correlation coefficients for the IMPROVE stations.

\begin{tabular}{llllllll}
\hline \multicolumn{8}{c}{ Station identifier } \\
\hline$R^{2}$ & ACAD & BOND & BOWA & BRET & CEBL & EVER & HALE \\
& 0.3 & 0.2 & 0.07 & 0.3 & 0.01 & 0.04 & 0.22 \\
$R^{2}$ & LASU & LYBR & MACA & MORA & OKEF & SIME & \\
& 0.08 & 0.14 & 0.14 & 0.4 & 0.20 & 0.01 & \\
\hline
\end{tabular}

Table 5. Comparison of modelled versus observed near-surface elemental carbon (EC) measurements.

\begin{tabular}{|c|c|c|c|c|c|c|c|}
\hline Station & Period & $\begin{array}{l}\text { Coordinates } \\
\text { (lat; lon) }\end{array}$ & Type & $\begin{array}{l}\text { Measured } \\
\text { EC } \\
\left(\mu \mathrm{g} / \mathrm{m}^{3}\right)\end{array}$ & $\begin{array}{l}\text { TM5/BULK } \\
\text { BC } \\
\left(\mu \mathrm{g} / \mathrm{m}^{3}\right)\end{array}$ & $\begin{array}{l}\text { TM5/DYNA } \\
\text { BC } \\
\left(\mu \mathrm{g} / \mathrm{m}^{3}\right)\end{array}$ & Reference \\
\hline FNS & Sep-Nov 2002 & $10.75 ; 62.35$ & Rural & 2.43 & 1.22 & 1.33 & Decesari et al. (2006) \\
\hline Zhenbeitai & Apr 2002 & $38.28 ; 109.72$ & Rural & 3.29 & 3.59 & 3.82 & Alfaro et al. (2003a) \\
\hline Kosan & Jan 1997 & $33 ; 126$ & Rural & 0.23 & 1.63 & 1.39 & Lee et al. (2001) \\
\hline Abastumani & Jul 1979 & $41.4 ; 42.5$ & Rural & 0.98 & 0.28 & 0.31 & Dzubay et al. (1984) \\
\hline Cape Grim & Annual & $-40.7 ; 144.4$ & Rural & 0.003 & 0.012 & 0.016 & Heintzenberg and Bigg (1990) \\
\hline Rishiri and Sado & Apr-May 2001 & $35-45 ; 140$ & Marine & 0.44 & 0.64 & 0.73 & Matsumoto et al. (2003) \\
\hline Hachijo and Chichi-Jima & Apr-May 2001 & $25-35 ; 140$ & Marine & 0.21 & 0.12 & 0.16 & Matsumoto et al. (2003) \\
\hline
\end{tabular}

Table 6. Comparison of modelled versus observed near-surface black carbon (BC) measurements.

\begin{tabular}{|c|c|c|c|c|c|c|c|}
\hline Station & Period & $\begin{array}{l}\text { Coordinates } \\
\text { (lat; lon) }\end{array}$ & Type & $\begin{array}{l}\text { Measured } \\
\text { BC } \\
\left(\mathrm{ng} / \mathrm{m}^{3}\right)\end{array}$ & $\begin{array}{l}\text { TM5/BULK } \\
\mathrm{BC} \\
\left(\mathrm{ng} / \mathrm{m}^{3}\right)\end{array}$ & $\begin{array}{l}\text { TM5/DYNA } \\
\text { BC } \\
\left(\mathrm{ng} / \mathrm{m}^{3}\right)\end{array}$ & Reference \\
\hline Amsterdam Island & Annual & $-37.5 ; 77.3$ & Marine & 8 & 1.2 & 3.9 & Wolff and Cachier (1998) \\
\hline Bermuda & Annual & $32.2 ; 64.45$ & Marine & 30 & 15 & 26.5 & Wolff et al. (1986) \\
\hline Ocean & Annual & $0 ;-160$ & Marine & 3 & 1.6 & 2.7 & $\begin{array}{l}\text { Andreae et al. (1984), } \\
\text { Clarke (1989) }\end{array}$ \\
\hline Mace Head & Apr 1998-Sep 1999 & $53.3 ;-9.8$ & Marine & 136 & 109 & 148 & Kleefeld et al. (2002) \\
\hline Prasses & May 1999 & $35.2 ; 25.1$ & Marine & 190 & 245 & 300 & Kouvarakis et al. (2002) \\
\hline Canal Zone, Panama & Mar 1976-May 1979 & $9.3 ; 79.9$ & Rural & 59 & 81 & 96 & Junker et al. (2004) \\
\hline Goa & Mar 1999 & $15.4 ; 74.8$ & Rural & 2180 & 1138 & 1170 & Alfaro et al. (2003b) \\
\hline Cuiaba & Annual & $-16 ;-56$ & Rural & 1620 & 580 & 717 & Echalar et al. (1998) \\
\hline Alta foresta & Annual & $-9 ;-56$ & Rural & 3190 & 1011 & 1255 & Echalar et al. (1998) \\
\hline Skukuza & Sep-Oct 1992 & $-25 ; 31.5$ & Rural & 1080 & 430 & 444 & Maenhaut et al. (1996) \\
\hline Lamto & Annual & $6.2 ; 5.1$ & Rural & 1500 & 399 & 420 & Wolff et Cachier (1998) \\
\hline
\end{tabular}


Table 7. Comparison of modelled and measured BC values spitted in dry and wet seasons for biomass burning sites.

\begin{tabular}{lllllll}
\hline Station & \multicolumn{3}{c}{ dry } & \multicolumn{3}{c}{ wet } \\
& Obs. & TM5/BULK & TM5/DYNA & Obs. & TM5/BULK & TM5/DYNA \\
\hline Cuiaba $\left(\mathrm{ng} / \mathrm{m}^{3}\right)$ & 2600 & 1204 & 1273 & 720 & 134 & 160 \\
Alta Foresta $\left(\mathrm{ng} / \mathrm{m}^{3}\right)$ & 5630 & 2210 & 2368 & 760 & 119 & 142 \\
\hline
\end{tabular}

observations. It is difficult to point to the right reason for this underestimation, it may be because for these sites we are comparing to $\mathrm{BC}$ measurements while the modelled values are more representative of EC estimates. Indeed the comparison with EC measurements in N. America and Europe does not show this bias. Alternatively the biomass burning emission inventories may simply underestimate emissions, or the injection height might be wrong. Furthermore, observations of both EC and BC, which are heavily influenced by biomass burning sources, are known to be modified by the presence in the sample of light-absorbing organic material that is not black, the so-called brown carbon (e.g. highly refractive organics determined as EC in thermal-optical methods and standard specific cross section used to derive BC concentrations in aethalometer measurements not appropriate for biomass burning aerosol) (Andreae and Gelencsér, 2006). Brown carbon can introduce a significant bias in the measurements and therefore also the emission factors estimated using these measurements can be affected as well, introducing another uncertainty in the emission inventory for biomass burning. The model underestimates observed BC concentrations at the Amazonian sites Cuiaba and Alta Foresta Basin (Echalar et al., 1998) in both the dry and wet seasons, as shown in Table 7. This suggests that emissions are too low in the biomass burning emission inventories used rather than the model overestimating wet removal over the biomass burning regions. Again the different aerosol representations do not produce significantly different results.

The comparison to observations at North and South Poles (Bodhaine, 1995; Wolff and Cachier, 1998; Pereira et al., 2006; Sharma et al., 2006) underlines the major differences between the two approaches (Figs. 5 and 6). The stations in the Arctic regions are influenced by anthropogenic sources located in Europe and in Russia, which impact mainly in late winter-spring time in the Arctic Haze (Sharma et al., 2004; Bodhaine, 1995; Eleftheriadis et al., 2009). During the winter-spring period the Antarctic sites are influenced by $\mathrm{BC}$ biomass burning emissions from the South Hemisphere that are transported to Antarctica (Wolff and Cachier, 1998; Pereira et al., 2006). The DYNA approach better represents the modelled BC levels at remote sites, while the BULK approach underestimates the concentrations by up to $1-2$ orders of magnitude. In Barrow both methods fail to reproduce the Arctic spring haze that is due to long-range transport of anthropogenic pollution (Bodhaine, 1995). In Alert DYNA does reproduce the seasonal cycle observed in the polar regions. In Zeppelin TM5-DYNA reproduces the observed BC concentrations very well, both the seasonal cycle and the absolute values; the observations in Zeppelin are representative of a regional background (Eleftheriadis et al., 2009), being influenced mostly by long-range transport. Only the measurements in Alert and Zeppelin were collected in the simulation years 2002 and 2003. In the Antarctic regions (Fig. 6) DYNA consistently gives better results, even though in Ferraz the underestimation of the measurements is still quite substantial.

To compare with the observed aircraft measurements vertical profiles of modelled $\mathrm{BC}$ are constructed averaging monthly mean fields (standard model output) at the locations correspondent to the flight tracks (see Koch et al., 2009 for the details of flight and tracks). It should be noted that the observed profiles are collected during a few days of flight and in different years to the modelled fields. Figure 7 shows the observed and modelled profiles over mid-latitude regions ( $a, d)$, in the tropics (b, c) and at high latitudes (e-i). The two model approaches behave in similar ways agreeing with the observations in one case (a) and underestimating the concentrations in (d) at mid-latitudes and overestimating the concentrations in the tropics at high levels in the tropics. The BULK model already estimates lower concentrations compared to the DYNA case, although the differences are small compared to the measurements. At high latitudes both the models underestimate the concentrations and the differences between the models is in some cases larger. Looking at the comparison of model results in the $\mathrm{BC}$ evaluation done in Koch et al. (2009) the results of our work fall in the same range, having the tendency to overestimate in the mid-latitude and tropic cases, except for case d) where all models underestimate the concentrations at lower levels. The same models generally underestimate BC in the high latitude cases. 

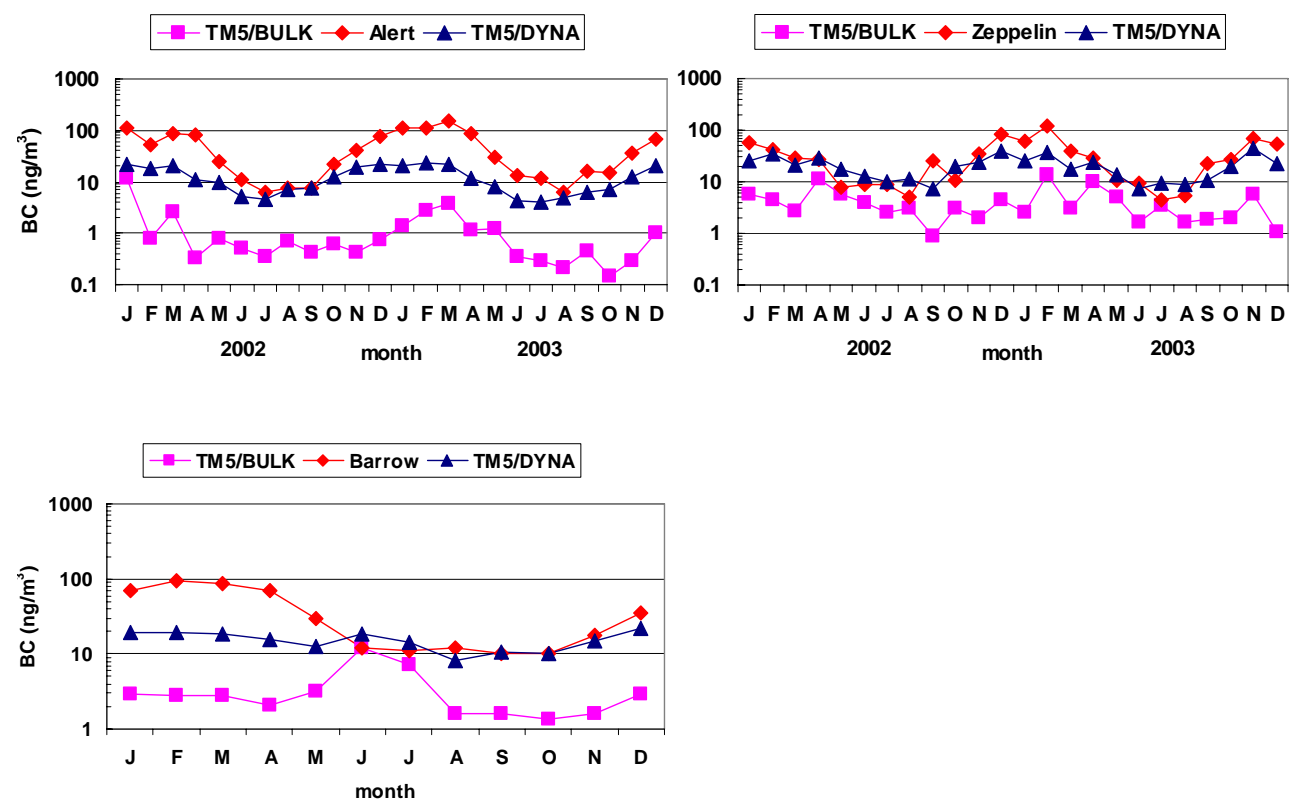

Fig. 5. Comparison of model (squared-TM5-BULK and triangle-TM5-DYNA) and observed (diamond) seasonal concentrations of BC at Arctic stations $\left(\mathrm{ng} / \mathrm{m}^{3}\right)$ (ambient conditions).
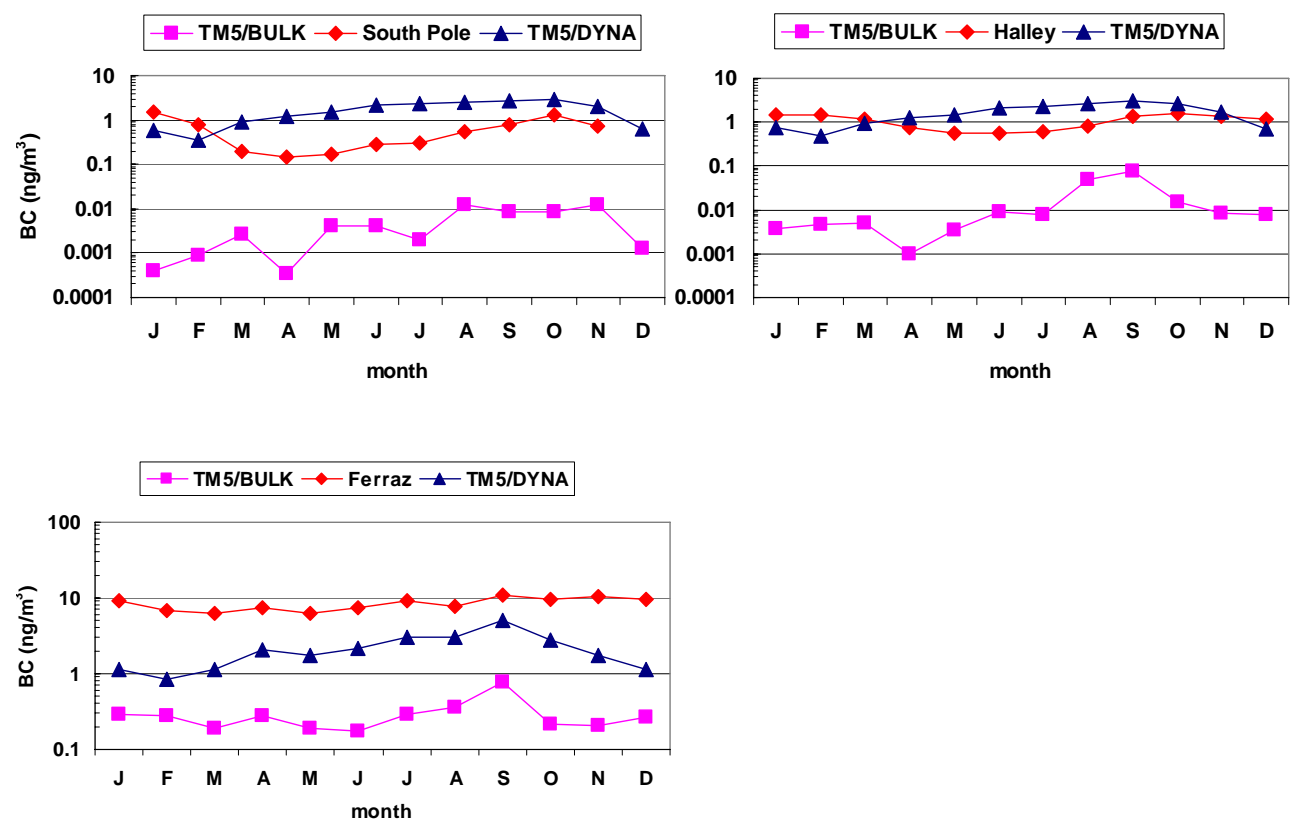

Fig. 6. Comparison of model (squared-TM5-BULK and triangle-TM5-DYNA) and observed (diamond) seasonal concentrations of BC at Antarctic stations ( $\mathrm{ng} / \mathrm{m}^{3}$ ) (ambient conditions).

\section{Discussion}

\subsection{Uncertainties related to the aerosol and wet removal schemes}

The differences between the results from the two models depend on the distance from the black carbon sources: in fact the ratio between BULK and DYNA surface concentrations

goes from about 1 over the continents to more than 10, up to orders of magnitude at the Antarctic area.

The crude assumption in the BULK approach of $30 \%$ of black carbon being interstitial and $70 \%$ being in-cloud removed very probably overestimates the wet removal since it does not take into account the hygroscopic state and the actual size of the particles and considers BC particles to be always totally soluble in clouds. In the case of coupling to M7 

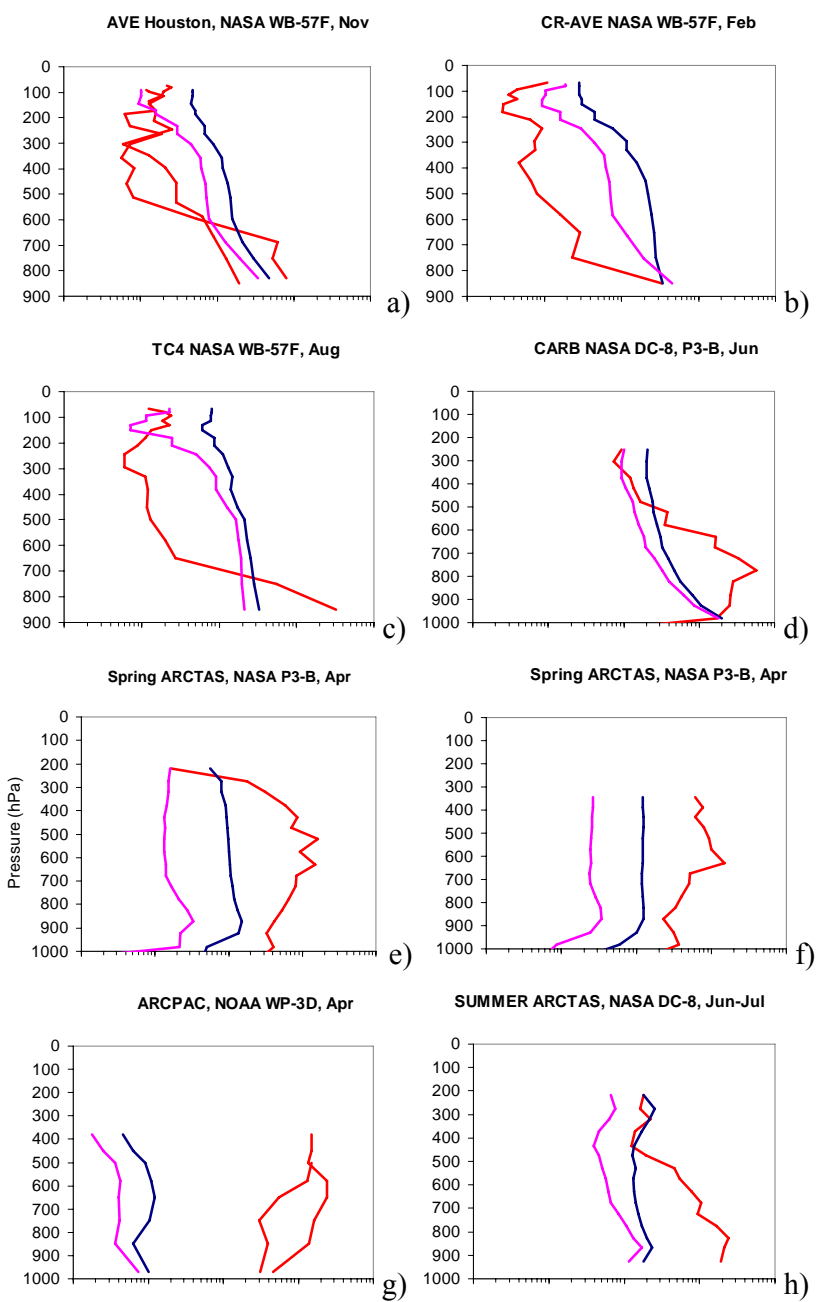

SUMMER ARCTAS, NASA P3-B, Jun-Jul
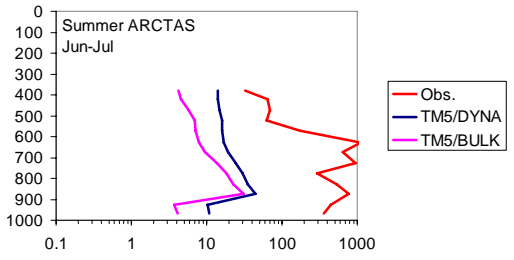

i)

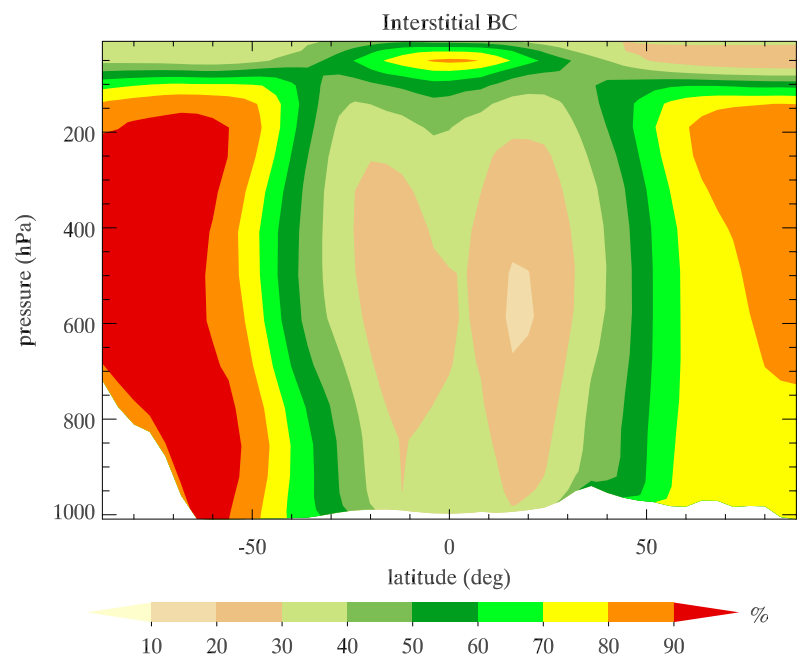

Fig. 8. Annual and zonal mean modelled interstitial BC mass, TM5DYNA case.

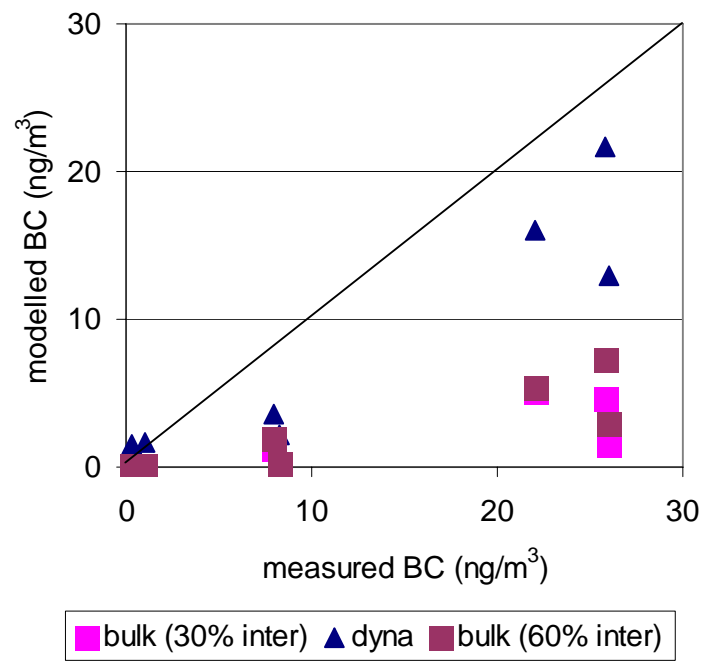

Fig. 9. Scatter-plot of modelled BC versus observations at remote stations.

in the rest of the model atmosphere the calculated interstitial fraction is much higher reaching the highest values at the Poles, because only the very low hygroscopicity particles will be transported so far from the sources. To test the effect of a more realistic interstitial fraction on the BULK model, TM5-BULK was run again with an average of $60 \%$ BC mass assumed to be interstitial. With the new values the model gives better results for the remote sites (Fig. 9). However the improvement is not marked suggesting that a global fixed percentage of interstitial aerosols does not correctly represent the transport, although these results depend on the parameterization for the wet removal used in TM5. The analysis of the vertical profiles in the case of $60 \%$ interstitial shows that at mid-latitudes and tropical regions the resulting $\mathrm{BC}$ falls 
Table 8. Sensitivity of BC wet deposition and lifetime (lsp = large scale precipitation, $\mathrm{cp}=$ convective precipitation) for May.

\begin{tabular}{lllll}
\hline Simulation & $\begin{array}{l}\text { Burden } \\
(\mathrm{Tg})\end{array}$ & $\begin{array}{l}\text { lsp deposition } \\
\left(\mathrm{Tg} \mathrm{yr}^{-1}\right)\end{array}$ & $\begin{array}{l}\text { cp deposition } \\
\left(\mathrm{Tg} \mathrm{yr}^{-1}\right)\end{array}$ & $\begin{array}{l}\text { Lifetime } \\
(\text { days })\end{array}$ \\
\hline Standard & 0.12 & 0.32 & 0.22 & 6.41 \\
lsp $-30 \%$ & 0.13 & 0.30 & 0.24 & 7.06 \\
$\mathrm{cp}-30 \%$ & 0.13 & 0.36 & 0.18 & 7.06 \\
lsp and cp - 30\% & 0.14 & 0.35 & 0.19 & 7.85 \\
No below cloud & 0.12 & 0.32 & 0.23 & 6.47 \\
\hline
\end{tabular}

between the DYNA and the BULK case. At high latitudes the $60 \%$ interstitial profile gets closer to the BULK case profile. Looking again at Fig. 8 it is clear that closer to high latitudes the DYNA approach estimates an interstitial fraction larger than 60-70\% up to more than $90 \%$ therefore the $60 \%$ hypothesis leads again in those areas to an overestimation of the wet removal. The major difference between the DYNA and BULK results in remote regions is due to the variable interstitial fraction and the fixed fraction, respectively.

Wet removal is the dominant sink for black carbon and the choice of the scheme in the model will determine BC burden and lifetime. The wet removal parameterisations used in TM5 have been evaluated in the AEROCOM intercomparison exercise (Textor et al., 2006) and found to be one of the strongest removal schemes among the 16 participant models.

Precipitation is taken from the ECMWF ERA-40 data, which have been evaluated using satellite and gauge measurements and reported in Hagermann et al. (2005) and in more recent works. Precipitation over the oceans is overestimated compared to measurements, which are uncertain. Over land precipitation is much closer to the observations although slightly overestimated. Betts et al. (2009) compared the ERA-40 data with observations in the Amazon Basis and found that the model underestimates precipitation during the wet season and overestimates in the dry season. Another precipitation evaluation was done for China and ERA-40 underestimates precipitations in most years (Ma et al., 2009). Betts et al. (2009) also evaluated the cloud cover using satellite measurements and showed that it has the same seasonal cycle of the retrieved data although underestimating it in the second part of the year.

To study the sensitivity of the BC burden and lifetime to wet removal, some simulations were performed using the DYNA model. In these tests, the wet removal due to large scale and convective precipitation were decreased by $30 \%$. In an additional test the below cloud scavenging by large scale precipitation was neglected. These sensitivity tests were performed for one month (May) with one month spin-up, but the results are considered representative, at least for a global analysis performed here.

Reduction of either scale or convective precipitation by $30 \%$ resulted in the same effect on BC lifetime. The burden and lifetime go up by approximately $10 \%$ (Table 8). Logically, the reduction of both large scale and convective removal by $30 \%$ produces the largest effect, the burden increases by $16 \%$ and lifetime goes up to 7.85 days $(+22 \%)$. Below cloud scavenging has a negligible effect on BC concentrations, since most of the BC is in the aitken and accumulation mode, for which below cloud removal is slow. The reduction of the wet removal has consequences for the transport of $\mathrm{BC}$ to the oceanic and remote areas: $\mathrm{BC}$ concentrations further away from the source regions increase by $10-20 \%$.

\subsection{Uncertainties related to the EC/BC measurement technique}

How well the model simulates real BC levels can be evaluated by comparison with measurements, as long as the model output is comparable to the measurements. As discussed above, this is not always the case for black carbon. The DYNA results are consistent with both the emission inventories being $\mathrm{EC}$ rather than $\mathrm{BC}$ and the coincident $\mathrm{BC}$ measurements being equal or larger than EC: the good agreements with EC over Europe; the ability to capture the seasonal trends in $\mathrm{BC}$ observations in polar regions, while not always reproducing the magnitude of the signal. In Alert the $\mathrm{BC}$ to $\mathrm{EC}$ ratio is equal to 1 in winter and to 1.5 in the summer (Sharma et al., 2004) while in Zeppelin the ratio is slightly less than 1 (Nyeki et al., 2005) therefore a slight under-prediction of observed $\mathrm{BC}$ in polar regions is consistent with our understanding.

The absolute uncertainty related to each measuring method is unknown; therefore no optical and thermal method can give the "real" amount of soot. Thermal and thermooptical methods estimate elemental carbon and are affected by uncertainties due to different protocols of temperature steps and use of the optics to monitor the charring used to separate the organic from the elemental fraction. The presence of salts in the sample can influence the estimation as well. Black carbon is quantified by optical methods which can measure only a signal proportional to the absorbing material collected on the sample. Dust and organic material can absorb light and if they are present the concentration of $\mathrm{BC}$ estimated with the assumption that the absorption is only 
due to soot can be overestimated (Andreae and Gelencsér, 2006), specially in the biomass burning and dust source regions.

Not only it is not possible to put an error bar around the black carbon/elemental carbon observations, but up to now no method is sufficiently ubiquitous to allow consistent comparable data set to be built at global scale, rendering the quantification of the "absolute" bias of the model compared to the whole dataset impossible; only a "relative" bias for each of the sub-datasets collected using a common method would be possible. As a consequence it is difficult to improve the model from an evaluation by comparison with such disparate and inconsistent observations.

\section{Conclusions and recommendations}

The aim of this study is to investigate important sources of uncertainties in the global $\mathrm{BC}$ estimates, by comparing the results of two common BC aerosol set-ups in a global model, by varying the strength of wet removal schemes and by their evaluation using measurements.

The global Chemistry-Transport Model TM5 has been applied to evaluate the sensitivity of the model to the black carbon description and processing using a bulk and a dynamical approach, respectively. The bulk scheme is very simple to include in a large scale model and very common, but with the wet removal scheme used in TM5 underestimates the concentrations far away from the sources compared to measurements. The crude assumption of a constant removal by rain is probably the main reason for this difference. Using the results of the dynamical model to calibrate the interstitial fraction in the bulk scheme doubles the fraction of aerosols assumed to be interstitial, but the transport to remote stations does not improve much and equally at all sites, pointing to the importance of the size dependent description of BC and its removal. Similarly, the dynamical model is relatively insensitive to feasible changes in efficiency of wet deposition: reducing both large scale and convective precipitation by $30 \%$ the increase of $\mathrm{BC}$ concentrations at remote regions is up to $20 \%$.

The observations available for an evaluation of a global model are sparse, and both measurements of EC and BC have to be used. The evaluation and further improvements of the modelled BC concentrations are not easy due to the quantification of the model bias to measurements, due to different methods used for their collections and analysis.

Increased understanding of not just the observational dataset and the uncertainties therein, but also the terminology surrounding black carbon is required not only to give a more coherent phenomenology of BC at global scale but also to underpin better model development.

Model output and observations used for comparison should be more consistent: emission inventories are representative of EC-like substance therefore a harmonized dataset of EC measurements is required, for which the fac- tor of difference among the thermal methods is accounted for. For sites and regions where the ratio of $\mathrm{BC}$ to $\mathrm{EC}$ mass is known, this ratio should be taken into account in the model comparison with $\mathrm{BC}$ observations.

For applications of the optical properties of BC, such as climate studies, it may be better to calculate the optical property (light absorption coefficient) from the model output, as this is directly comparable with the observed aerosol property. In this case emission inventories should also take into account the mass of absorbing organic material which contributes to the total absorption but not considered yet in the current inventories. However, the radiative properties of organics, including the imaginary part of the refractive index important for absorption, are barely known and measurements are required to include them in models.

\section{Appendix A}

Convection in chemistry transport models like TM5 is a subgrid process, which means that the process is parameterized. In the model different resolutions are employed in a single simulation, which means that special care should be taken so that the parameterisations do not depend on the model resolution and time-step. For wet removal by convective precipitation it was found that the resolution dependency is small for the following empirical relation between the scavenging efficiency $S$ and the grid-box averaged convective precipitation rate $\mathrm{cp}\left(\mathrm{mm} \mathrm{hr}^{-1}\right)$ :

$S=\left(1-e^{-\frac{\mathrm{cp}}{0.5}}\right)$

The scavenging efficiency is applied in the routine that performs the sub-grid scale convective redistribution of the tracers. Specifically, it is assumed that the removal takes place in the precipitating updraft of the convective column:

$$
\frac{d A}{d t}=-S \cdot \frac{M_{\mathrm{u}}}{M} \cdot A
$$

where $A$ is the tracer concentration along the updraft column, $M_{\mathrm{u}}$ is the updraft $\left(\mathrm{kg} \mathrm{s}^{-1}\right)$ and $M$ represents the mass of the specific gridbox $(\mathrm{kg})$.

Removal of aerosols in large scale precipitating system may also exhibit a strong dependency on the model resolution and the removal efficiency may also depend strongly on the time-step used. A reasonable solution is to introduce a mixing time-scale $\tau_{\text {nomix }}$. For large-scale wet removal, the model grid box is divided into three parts: (i) in cloud (ii) below cloud (iii) cloud free, each characterised by a removal rate (see below). The physical interpretation of $\tau_{\text {nomix }}$ is the time-scale for which we assume that these three regions remain separated. Since the ECMWF large-scale precipitation fields are stored as three hourly accumulated values, a value $\tau_{\text {nomix }}=3 \mathrm{~h}$ was selected. The main effect of this assumption is that the wet removal will be slower and that resolution dependency will be smaller. The implementation of $\tau_{\text {nomix }}$ is 
particularly simple. Given the in-cloud and below cloud removal rates $L_{\text {in }}$ and $L_{\text {below }}\left(\mathrm{s}^{-1}\right)$, the following loss factors $(F)$ are calculated:

$$
\begin{aligned}
& F_{\text {in }}=e^{-\tau_{\text {nomix }} L_{\text {in }}} \\
& F_{\text {below }}=e^{-\tau_{\text {nomix }} L_{\text {below }}}
\end{aligned}
$$

Given the grid box fractions that reside in, below, and out of the clouds ( $f_{\text {in }}, f_{\text {below }}$, and $f_{\text {out }}$ ), the concentration of a tracer $\mathrm{A}$ is updated accordingly to:

$A_{t+d t}=A_{t}\left(\left(f_{\text {in }} F_{\text {in }}+f_{\text {below }} F_{\text {below }}+f_{\text {out }}\right)^{\frac{d t}{\tau_{\text {nomix }}}}\right)$

with time step $d t(<3 \mathrm{~h})$.

For both convective and stratiform removal rates of aerosols insufficient information is currently available to develop a well-funded description. Future and ongoing theoretical and experimental work will hopefully reduce this large uncertainty.

Acknowledgements. We acknowledge the help of Arjo Segers with the implementation of the TM5 code, Stefano Decesari for the measurements in Rondonia, Stephan Nyeki and Kostas Eleftheriadis for the measurements in Zeppelin. Dorothy Koch is acknowledged for providing the vertical profile measurements. We thank Tami Bond for discussing the use of EC and BC measurements; HansChristen Hansson and Frank Dentener for reviewing the manuscript.

Edited by: J. H. Seinfeld

\section{References}

Alfaro, S. C., Gomes, L., Rajot, J. L., Lafon, S., Gaudichet, A., Chatenet, B., Maille, M., Cautenet, G., Lasserre, F., Cachier, H., and Zhang, X. Y.: Chemical and optical characterization of aerosols measured in spring 2002 at the ACE-Asia supersite, Zhenbeitai, China, J. Geophys. Res.-Atmos., 108(D23), 8641, doi:10.1029/2002JD003214, 2003a.

Alfaro, S. C., Gaudichet, A., Rajot, J. L., Gomes, L., Maille, M., and Cachier, H.: Variability of aerosol size-resolved composition at an Indian coastal site during the Indian Ocean Experiment (INDOEX) intensive field phase, J. Geophys. Res.-Atmos., 108(D8), 4235, doi:10.1029/2002JD002645, 2003 b.

Andreae, M. O., Andreae, T. W., Ferek, R. J., and Raemdonck, H.: Long-range transport of soot carbon in the marine atmosphere, Sci. Total Environ., 36, 73-80, 1984.

Andreae, M. O. and Merlet., P.: Emission of trace gases and aerosols from biomass burning, Global Biogeochem. Cy., 15, 955-966, 2001.

Andreae, M. O. and Gelencsér, A.: Black carbon or brown carbon? The nature of light-absorbing carbonaceous aerosols, Atmos. Chem. Phys., 6, 3131-3148, 2006, http://www.atmos-chem-phys.net/6/3131/2006/.

Bergamaschi, P., Meirink, J. F., Müller, J. F., Körner, S., Heimann, M., Bousquet, P., Dlugokencky, E. J., Kaminski, U., Vecchi, R., Marcazzan, G., Meinhardt, F., Ramonet, M., Sartorius, H., and Zahorowski, W.: Model Inter-comparison on Transport and
Chemistry - report on model inter-comparison performed within European Commission FP5 project EVERGREEN Report EUR 22241 EN, 53 pp., 2006.

Betts, A. K., Köhler, M., and Zhang, Y.: Comparison of river basin hydrometeorology in ERA-Interim and ERA-40 reanalyses with observations, J. Geophys. Res., 114, D02101, doi:10.1029/2008JD010761, 2009.

Bodhaine, B. A.: Aerosol absorption measurements at Barrow, Mauna Loa and the south pole, J. Geophys. Res., 100, 89678975, 1995.

Bond, T. C., Streets, D. G., Yarber, K. F., Nelson, S. M., Woo, J. H., and Klimont, Z.: A technology-based global inventory of black and organic carbon emissions from combustion, J. Geophys. Res.-Atmos., 109, D14203, doi:10.1029/2003JD003697, 2004.

Bond, T. C. and Bergstrom, R. W.: Light absorption by carbonaceous particles: An investigative review, Aerosol Sci. Tech., 40, $1-41,2006$.

Chow, J. C., Watson, J.G., Crow, D., Lowenthal, D.H., and Merrifield, T.: Comparison of IMPROVE and NIOSH carbon measurements, Aerosol Sci. Tech., 34, 23-34, 2001.

Chung, S. H. and Seinfeld, J. H.: Global distribution and climate forcing of carbonaceous aerosols, J. Geophys. Res., 107(D19), 4407, doi:10.1029/2001JD001397, 2002.

Clarke, A. D.: Aerosol light absorption by soot in remote environments, Aerosol Sci. Tech., 10, 161-171, 1989.

Cofala, J., Amann, M., Klimont, Z., Kupiainen, K., and HöglundIsaksson, L.: Scenarios of global anthropogenic emissions of air pollutants and methane until 2030, Atmos. Environ., 41, 84868499, 2007

Cooke, W. F. and Wilson, J. J. N.: A global black carbon aerosol model, J. Geophys. Res.-Atmos., 101, 19395-19409, 1996.

Croft, B., Lohmann, U., and von Salzen, K.: Black carbon ageing in the Canadian Centre for Climate modelling and analysis atmospheric general circulation model, Atmos. Chem. Phys., 5, 19311949, 2005, http://www.atmos-chem-phys.net/5/1931/2005/.

Currie, L. A., Benner Jr., B. A., Kessler, J. D., Klinedinst, D. B., Klouda, G. A., Marolf, J. V., Slater, J. F., Wise, S. A., Cachier, H., Cary, R., Chow, J. C., Watson, J., Druffel, E. R. M., Masiello, C. A., Eglinton, T. I., Pearson, A., Reddy, C. M., Gustafsson, O., Quinn, J. G., Hartmann, P. C., Hedges, J. I., Prentice, K. M., Kirchstetter, T. W., Novakov, T., Puxbaum, H., and Schmid, H.: A critical evaluation of interlaboratory data on total, elemental, and isotopic carbon in the carbonaceous particle reference material, NIST SRM 1649a, J. Res. Natl. Inst. Stan., 107, 279-298, 2002.

Dana, M. T. and Hales, J. M.: Statistical aspects of the washout of polydisperse aerosols, Atmos. Environ., 10, 45-50, 1976.

de Meij, A., Krol, M., Dentener, F., Vignati, E., Cuvelier, C., and Thunis, P.: The sensitivity of aerosol in Europe to two different emission inventories and temporal distribution of emissions, Atmos. Chem. Phys., 6, 4287-4309, 2006, http://www.atmos-chem-phys.net/6/4287/2006/.

Decesari, S., Fuzzi, S., Facchini, M. C., Mircea, M., Emblico, L., Cavalli, F., Maenhaut, W., Chi, X., Schkolnik, G., Falkovich, A., Rudich, Y., Claeys, M., Pashynska, V., Vas, G., Kourtchev, I., Vermeylen, R., Hoffer, A., Andreae, M. O., Tagliavini, E., Moretti, F., and Artaxo, P.: Characterization of the organic composition of aerosols from Rondnia, Brazil, during the LBA- 
SMOCC 2002 experiment and its representation through model compounds, Atmos. Chem. Phys., 6, 375-402, 2006,

http://www.atmos-chem-phys.net/6/375/2006/.

Dentener, F., Stevenson, D., Cofala, J., Mechler, R., Amann, M., Bergamaschi, P., Raes, F., and Derwent, R.: The impact of air pollutant and methane emission controls on tropospheric ozone and radiative forcing: CTM calculations for the period 19902030, Atmos. Chem. Phys., 5, 1731-1755, 2005, http://www.atmos-chem-phys.net/5/1731/2005/.

Dentener, F., Kinne, S., Bond, T., Boucher, O., Cofala, J., Generoso, S., Ginoux, P., Gong, S., Hoelzemann, J. J., Ito, A., Marelli, L., Penner, J. E., Putaud, J.-P., Textor, C., Schulz, M., van der Werf, G. R., and Wilson, J.: Emissions of primary aerosol and precursor gases in the years 2000 and 1750 prescribed data-sets for AeroCom, Atmos. Chem. Phys., 6, 4321-4344, 2006,

http://www.atmos-chem-phys.net/6/4321/2006/.

Dzubay, T. G., Stevens, R. K., and Haagenson, P. L.: Composition and origins of aerosol at a forested mountain in Soviet Georgia, Environ. Sci. Technol., 18, 873-883, 1984.

Echalar, F., Artaxo, P., Martins, J. V., Yamasoe, M., Gerab, F., Maenhaut, W., and Holben, B.: Long-term monitoring of atmospheric aerosols in the amazon basin: Source identification and apportionment, J. Geophys. Res.-Atmos., 103, 31849-31864, 1998.

Eleftheriadis, K., Vratolis, S., and Nyeki, S.: Aerosol black carbon in the European Arctic: Measurements at Zeppelin station, Ny-Ålesund, Svalbard from 1998-2007, Geophys. Res. Lett., 36, L02809, doi:10.1029/2008GL035741, 2009.

Fassi-Fihri, A., Suhre, K., and Rosset, R.: Internal and external mixing in atmospheric aerosols by coagulation: Impact on the optical and hygroscopic properties of the sulphate-soot system, Atmos. Environ., 31, 1393-1402, 1997.

Ganzeveld, L. and Lelieveld, J.: Dry deposition parameterization in a chemistry general circulation model and its influence on the distribution of reactive trace gases, J. Geophys. Res., 100, 20999-921012, 1995.

Gery, M. W., Whitten, G. Z., and Killus, J. P: Development and testing of the CBM-IV for urban and regional modelling, US EPA, Research Triangle Park EPA-600/3-88-012, 1989a.

Gery, M. W., Whitten, G. Z., Killus, J. P., and Dodge, M. C.: A photochemical kinetics mechanism for urban and regional scale computer modeling, J. Geophys. Res., 94, 12925-912956, 1989b.

Gong, S. L.: A parameterization of sea-salt aerosol source function for sub- and super-micron particles, Global Biogeochem. Cy., 17(4), 1097, doi:10.1029/2003GB002079, 2003.

Gong, S. L., Barrie, L. A., Blanchet, J. P., von Salzen, K., Lohmann, U., Lesins, G., Spacek, L., Zhang, L. M., Girard, E., Lin, H., Leaitch, R., Leighton, H., Chylek, P., and Huang, P.: Canadian Aerosol Module: A size-segregated simulation of atmospheric aerosol processes for climate and air quality models 1. Module development, J. Geophys. Res.-Atmos., 108, 4007, doi:10.1029/2001JD002002, 2003.

Guelle, W., Balkanski, Y. J., Schulz, M., Dulac, F., and Monfray, P.: Wet deposition in a global size-dependent aerosol transport model. 1. Comparison of a 1 year $210 \mathrm{~Pb}$ simulation with ground measurements, J. Geophys. Res.-Atmos., 103, 1142911445, 1998.

Guillaume, B., Liousse, C., Rosset, R., Cachier, H., Van Velthoven,
P., Bessagnet, B., and Poisson, N.: ORISAM-TM4: A new global sectional multi-component aerosol model including SOA formation - Focus on carbonaceous BC and OC aerosols, Tellus B, 59, 283-302, 2007.

Hagemann, S., Arpe, K., and Bengtsson, L.: Validation of the hydrological cycle of ERA-40, ERA-40 Project Report Series, ECMWF, Reading, England, 2005.

Haywood, J. M. and Shine, K. P.: The effect of anthropogenic sulfate and soot aerosol on the clear sky planetary radiation budget, Geophys. Res. Lett., 22, 603-606, 1995.

Heintzenberg, J. and Bigg, E. K.: Tropospheric transport of trace substances in the Southern Hemisphere, Tellus B, 42, 355-363, 1990.

Hertel, O., Berkowicz, R., Christensen, J., and Hov, O.: Test of two numerical schemes for use in atmospheric transport-chemistry models, Atmos. Environ. A-Gen, 27, 2591-2611, 1993.

Hitzenberger, R., Berner, A., Giebl, H., Kromp, R., Larson, S. M., Rouc, A., Koch, A., Marischka, S., and Puxbaum, H.: Contribution of carbonaceous material to cloud condensation nuclei concentrations in European background (Mt. Sonnblick) and urban (Vienna) aerosols, Atmos. Environ., 33, 2647-2659, 1999.

Hitzenberger, R., Petzold, A., Bauer, H., Ctyroky, P., Pouresmaeil, P., Laskus, L., and Puxbaum, H.: Intercomparison of thermal and optical measurement methods for elemental carbon and black carbon at an urban location, Environ. Sci. Technol., 40, 63776383, 2006.

Houweling, S., Dentener, F., and Lelieveld, J.: The impact of nonmethane hydrocarbon compounds on tropospheric photochemistry, J. Geophys. Res., 103, 10673-10696, 1998.

IPCC: The Physical Science Basis, in: Contribution of Working Group I ot the Fourth Assessment Report of the Intergovernmental Panel on Climate Change, ISBN 9780521 88009-1 Hardback; 9780521 70596-7 Paperback, 2007.

Jacobson, M. Z.: Global direct radiative forcing due to multicomponent anthropogenic and natural aerosols, J. Geophys. Res.Atmos., 106, 1551-1568, 2001.

Jacobson, M. Z.: Control of fossil-fuel particulate black carbon and organic matter, possibly the most effective method of slowing global warming, J. Geophys. Res.-Atmos., 107(D19), 4410, doi:10.1029/2001JD001376, 2002.

Jeong, C.-H., Hopke, P. K., Kim, E., and Lee, D.-W.: The comparison between thermal-optical transmittance elemental carbon and Aethalometer black carbon measured at multiple monitoring sites, Atmos. Environ., 38, 5193-5204, 2004.

Jeuken, A., Veefkind, J. P., Dentener, F., Metzger, S., and Robles Gonzalez, C.: Simulation of the aerosol optical depth over Europe for August 1997 and a comparison with observations, J. Geophys. Res.-Atmos., 106, 28295-28311, 2001.

Junker, C., Sheahan, J. N., Jennings, S. G., O’Brien, P., Hinds, B. D., Martinez-Twary, E., Hansen, A. D. A., White, C., Garvey, D. M., and Pinnick, R. G.: Measurement and analysis of aerosol and black carbon in the southwestern United States and Panama and their dependence on air mass origin, J. Geophys. Res.-Atmos., 109, D13201, doi:10.1029/2003JD004066, 2004.

Junker, C. and Liousse, C.: A global emission inventory of carbonaceous aerosol from historic records of fossil fuel and biofuel consumption for the period 1860-1997, Atmos. Chem. Phys., 8, 1195-1207, 2008, http://www.atmos-chem-phys.net/8/1195/2008/. 
Kasper-Giebl, A., Koch, A., Hitzenberger, R., and Puxbaum, H.: Scavenging efficiency of "Aerosol carbon" and sulfate in supercooled clouds at Mt. Sonnblick (3106 m a.s.1., Austria), J. Atmos. Chem., 35, 33-46, 2000.

Kettle, A. J., Andreae, M. O., Amouroux, D., Andreae, T. W., Bates, T. S., Berresheim, H., Bingemer, H., et al.: A global database of sea surface dimethylsulfide (DMS) measurements and a procedure to predict sea surface DMS as a function of latitude, longitude, and month, Global Biogeochem. Cy., 13(2), 399-444, 1999.

Kleefeld, S., Hoffer, A., Krivácsy, Z., and Jennings, S. G.: Importance of organic and black carbon in atmospheric aerosols at Mace Head, on the West Coast of Ireland $\left(53^{\circ} 19^{\circ} \mathrm{N}, 9^{\circ} 54^{\circ} \mathrm{W}\right)$, Atmos. Environ., 36, 4479-4490, 2002.

Koch, D. and Hansen, J.: Distant origins of Arctic black carbon: A Goddard Institute for Space Studies ModelE experiment, J. Geophys. Res.-Atmos., 110, D04204, doi:10.1029/2004JD005296, 2005.

Koch, D., Bond, T. C., Streets, D., Unger, N., and van der Werf, G. R.: Global impacts of aerosols from particular source regions and sectors, J. Geophys. Res.-Atmos., 112, D02205, doi:10.1029/2005JD007024, 2007.

Koch, D., Schulz, M., Kinne, S., McNaughton, C., Spackman, J. R., Balkanski, Y., Bauer, S., Berntsen, T., Bond, T. C., Boucher, O., Chin, M., Clarke, A., De Luca, N., Dentener, F., Diehl, T., Dubovik, O., Easter, R., Fahey, D. W., Feichter, J., Fillmore, D., Freitag, S., Ghan, S., Ginoux, P., Gong, S., Horowitz, L., Iversen, T., Kirkevåg, A., Klimont, Z., Kondo, Y., Krol, M., Liu, X., Miller, R., Montanaro, V., Moteki, N., Myhre, G., Penner, J. E., Perlwitz, J., Pitari, G., Reddy, S., Sahu, L., Sakamoto, H., Schuster, G., Schwarz, J. P., Seland, Ø., Stier, P., Takegawa, N., Takemura, T., Textor, C., van Aardenne, J. A., and Zhao, Y.: Evaluation of black carbon estimations in global aerosol models, Atmos. Chem. Phys., 9, 9001-9026, 2009,

http://www.atmos-chem-phys.net/9/9001/2009/.

Kouvarakis, G., Doukelis, Y., Mihalopoulos, N., Rapsomanikis, S., Sciare, J., and Blumthaler, M.: Chemical, physical, and optical characterization of aerosols during PAUR II experiment, J. Geophys. Res.-Atmos., 107(D18), 8141, doi:10.1029/2000JD000291, 2002.

Krol, M., Houweling, S., Bregman, B., van den Broek, M., Segers, A., van Velthoven, P., Peters, W., Dentener, F., and Bergamaschi, P.: The two-way nested global chemistry-transport zoom model TM5: algorithm and applications, Atmos. Chem. Phys., 5, 417432, 2005, http://www.atmos-chem-phys.net/5/417/2005/.

Lee, J. H., Kim, Y. P., Moon, K. C., Kim, H. K., and Lee, C. B.: Fine particle measurements at two background sites in Korea between 1996 and 1997, Atmos. Environ., 35, 635-643, 2001.

Liousse, C., Penner, J. E., Chuang, C., Walton, J. J., Eddleman, H., and Cachier, H.: A global three-dimensional model study of carbonaceous aerosols, J. Geophys. Res.-Atmos., 101, 1941119432, 1996.

Liss, P. and Merlivat, L.: The role of sea-air exchange in geochemical cycling, edited by: Menard, P., Reidel, Dordrecht, 113-127, 1986.

Ma, L., Zhang, T., Frauenfeld, O. W., Ye, B., Yang, D., and Qin, D.: Evaluation of precipitation from the ERA-40, NCEP-1, and NCEP-2 Reanalyses and CMAP-1, CMAP-2, and GPCP-2 with ground-based measurements in China, J. Geophys. Res., 114,
D09105, doi:10.1029/2008JD011178, 2009.

Maenhaut, W., Salma, I., Cafmeyer, J., Annegarn, H. J., and Andreae, M. O.: Regional atmospheric aerosol composition and sources in the eastern Transvaal, South Africa, and impact of biomass burning, J. Geophys. Res.-Atmos., 101, 23631-23650, 1996.

Matsumoto, K., Uematsu, M., Hayano, T., Yoshioka, K., Tanimoto, H., and Iida, T.: Simultaneous measurements of particulate elemental carbon on the ground observation network over the western North Pacific during the ACE-Asia campaign, J. Geophys. Res.-Atmos., 108(D23), 8635, doi:10.1029/2002JD002744, 2003.

Nyeki, S., Bauer, H., Puxbaum, H., Dye, C., Teinila, K., Hillamo, R., Ström, J., and Eleftheriadis, K.: Comparison of Black Carbon concentrations derived by filter-based light transmission and thermo-optical techniques for Arctic aerosol, in: Proceedings of the European Aerosol Conference, Ghent, Belgium, 28 August-2 September 2005, 122 pp., 2005.

Penner, J. E., Eddleman, H., and Novakov, T.: Towards the development of a global inventory for black carbon emissions, Atmos. Environ. A-Gen, 27, 1277-1295, 1993.

Pereira, E. B., Evangelista, H., Pereira, K. C. D., Cavalcanti, I. F. A., and Setzer, A. W.: Apportionment of black carbon in the South Shetland Islands, Antartic Peninsula, J. Geophys. Res.-Atmos., 111, D03303, doi:10.1029/2005JD006086, 2006.

Peters, W., Krol, M. C., Dlugokencky, E. J., Dentener, F. J., Bergamaschi, P., Dutton, G., Velthoven, P. V., Miller, J. B., Bruhwiler, L., and Tans, P. P.: Toward regional-scale modeling using the two-way nested global model TM5: Characterization of transport using SF6, J. Geophys. Res.-Atmos., 109, D19314, doi:10.1029/2004JD005020, 2004.

Petersen, A. C., Spee, E. J., Dop, H. V., and Hundsdorfer, W.: An evaluation and intercomparison of four new advection schemes for use in global chemistry models, J. Geophys. Res., 103, 19253-19269, 1998

Pöschl, U., Letzel, T., Schauer, C., and Niessner, R.: Interaction of ozone and water vapor with spark discharge soot aerosol particles coated with benzo[a]pyrene: $\mathrm{O}_{3}$ and $\mathrm{H}_{2} \mathrm{O}$ adsorption, benzo[a]pyrene degradation, and atmospheric implications, J. Phys. Chem. A, 105, 4029-4041, 2001.

Reddy, M. S. and Boucher, O.: Climate impact of black carbon emitted from energy consumption in the world's regions, Geophys. Res. Lett., 34, L11802, doi:10.1029/2006GL028904, 2007.

Reisinger, P., Wonaschütz, A., Hitzenberger, R., Petzold, A., Bauer, H., Jankowski, N., Puxbaum, H., Chi, X., and Maenhaut, W.: Intercomparison of measurement techniques for black or elemental carbon under urban background conditions in wintertime: Influence of biomass combustion, Environ. Sci. Technol., 42, 884889, 2008.

Russell, G. L. and Lerner, J. A.: A new finite-differencing scheme for the tracer transport equation. J. Appl. Meteorol., 20, 14831498, 1981.

Schaap, M., Denier Van Der Gon, H. A. C., Dentener, F. J., Visschedijk, A. J. H., Van Loon, M., ten Brink, H. M., Putaud, J. P., Guillaume, B., Liousse, C., and Builtjes, P. J. H.: Anthropogenic black carbon and fine aerosol distribution over Europe, J. Geophys. Res.-Atmos., 109, D18207, doi:10.1029/2003JD004330, 2004.

Schmid, H., Laskus, L., Jürgen Abraham, H., Baltensperger, U., La- 
vanchy, V., Bizjak, M., Burba, P., Cachier, H., Crow, D., Chow, J., Gnauk, T., Even, A., Ten Brink, H. M., Giesen, K. P., Hitzenberger, R., Hueglin, C., Maenhaut, W., Pio, C., Carvalho, A., Putaud, J. P., Toom-Sauntry, D., and Puxbaum, H.: Results of the "carbon conference" international aerosol carbon round robin test stage I, Atmos. Environ., 35, 2111-2121, 2001.

Seinfeld, J. H. and Pandis, S. N.: Atmospheric chemistry and physics: from air pollution to climate change, J. Wiley, New York, Chichester, xxvii, 1326 pp., 1998.

Sharma, S., Lavoue, D., Chachier, H., Barrie, L. A., and Gong, S. L.: Long-term trends of the black carbon concentrations in the Canadian Arctic, J. Geophys. Res.-Atmos., 109, D15203 1520115210, 2004.

Sharma, S., Andrews, E., Barrie, L. A., Ogren, J. A., and Lavoue, D.: Variations and sources of the equivalent black carbon in the high Arctic revealed by long-term observations at Alert and Barrow: 1989-2003, J. Geophys. Res.-Atmos., 111, D14208, doi:10.1029/2005JD006581, 2006.

Schwarz, J. P., Gao, R. S., Fahey, D. W., et al.: Single-particle measurements of midlatitude black carbon and lightscattering aerosols from the boundary layer to the lower stratosphere, J. Geophys. Res., 111, D16207, doi:10.1029/2006JD007076, 2006.

Slowik, J. G., Cross, E. S., Han, J.-H., et al.: An intercomparison of instruments measuring black carbon content of soot particles, Aerosol Sci. Tech., 41, p. 295, 2007.

Spracklen, D. V., Pringle, K. J., Carslaw, K. S., Mann, G. W., Manktelow, P., and Heintzenberg, J.: Evaluation of a global aerosol microphysics model against size-resolved particle statistics in the marine atmosphere, Atmos. Chem. Phys., 7, 2073-2090, 2007, http://www.atmos-chem-phys.net/7/2073/2007/.

Stier, P., Feichter, J., Kinne, S., Kloster, S., Vignati, E., Wilson, J., Ganzeveld, L., Tegen, I., Werner, M., Balkanski, Y., Schulz, M., Boucher, O., Minikin, A., and Petzold, A.: The aerosolclimate model ECHAM5-HAM, Atmos. Chem. Phys., 5, 11251156, 2005, http://www.atmos-chem-phys.net/5/1125/2005/.

Stier, P., Feichter, J., Kloster, S., Vignati, E., and Wilson, J.: Emission-induced nonlinearities in the global aerosol system: Results from the ECHAM5-HAM aerosol-climate model, J. Climate, 19, 3845-3862, 2006.

Stier, P., Seinfeld, J. H., Kinne, S., and Boucher, O.: Aerosol absorption and radiative forcing, Atmos. Chem. Phys., 7, 52375261, 2007, http://www.atmos-chem-phys.net/7/5237/2007/.

Ström, J., Okada, K., and Heintzenberg, J.: On the state of mixing of particles due to Brownian coagulation, J. Aerosol Sci., 23, 467-480, 1992.

Tegen, I., Hollrig, P., Chin, M., Fung, I., Jacob, D., and Penner, J.: Contribution of different aerosol species to the global aerosol extinction optical thickness: Estimates from model results, J. Geophys. Res.-Atmos., 102, 23895-23915, 1997.

ten Brink, H., Maenhaut, W., Hitzenberger, R., Gnauk, T., Spindler, G., Even, A., Chi, X., Bauer, H., Puxbaum, H., Putaud, J. P., Tursic, J., and Berner, A.: INTERCOMP2000: The comparability of methods in use in Europe for measuring the carbon content of aerosol, Atmos. Environ., 38, 6507-6519, 2004.

Textor, C., Schulz, M., Guibert, S., Kinne, S., Balkanski, Y., Bauer, S., Berntsen, T., Berglen, T., Boucher, O., Chin, M., Dentener, F., Diehl, T., Easter, R., Feichter, H., Fillmore, D., Ghan, S., Ginoux, P., Gong, S., Grini, A., Hendricks, J., Horowitz, L., Huang, P., Isaksen, I., Iversen, I., Kloster, S., Koch, D., Kirkevåg, A.,
Kristjansson, J. E., Krol, M., Lauer, A., Lamarque, J. F., Liu, X., Montanaro, V., Myhre, G., Penner, J., Pitari, G., Reddy, S., Seland, Ø., Stier, P., Takemura, T., and Tie, X.: Analysis and quantification of the diversities of aerosol life cycles within AeroCom, Atmos. Chem. Phys., 6, 1777-1813, 2006,

http://www.atmos-chem-phys.net/6/1777/2006/.

Textor, C., Schulz, M., Guibert, S., Kinne, S., Balkanski, Y., Bauer, S., Berntsen, T., Berglen, T., Boucher, O., Chin, M., Dentener, F., Diehl, T., Feichter, J., Fillmore, D., Ginoux, P., Gong, S., Grini, A., Hendricks, J., Horowitz, L., Huang, P., Isaksen, I. S. A., Iversen, T., Kloster, S., Koch, D., Kirkevåg, A., Kristjansson, J. E., Krol, M., Lauer, A., Lamarque, J. F., Liu, X., Montanaro, V., Myhre, G., Penner, J. E., Pitari, G., Reddy, M. S., Seland, Ø., Stier, P., Takemura, T., and Tie, X.: The effect of harmonized emissions on aerosol properties in global models - an AeroCom experiment, Atmos. Chem. Phys., 7, 4489-4501, 2007, http://www.atmos-chem-phys.net/7/4489/2007/.

Tsigaridis, K. and Kanakidou, M.: Global modelling of secondary organic aerosol in the troposphere: a sensitivity analysis, Atmos. Chem. Phys., 3, 1849-1869, 2003,

http://www.atmos-chem-phys.net/3/1849/2003/.

Van Der Werf, G. R., Randerson, J. T., Collatz, G. J., Giglio, L., Kasibhatla, P. S., Arellano Jr., A. F., Olsen, S. C., and Kasischke, E. S.: Continental-Scale Partitioning of Fire Emissions during the 1997 to 2001 El Niño/La Niña Period, Science, 303, 73-76, 2004.

Vignati, E., Wilson, J., and Stier, P.: M7: An efficient sizeresolved aerosol microphysics module for large-scale aerosol transport models, J. Geophys. Res.-Atmos., 109, D22202, doi:10.1029/2003JD004485, 2004.

Vignati, E., Facchini, M. C., Rinaldi, M., Scannell, C., Ceburnis, D., Sciare, J., Kanakidou, M., Myriokefalitakis, S., Dentener, F., and O'Dowd, C. D.: Global scale emission and distribution of sea spray aerosol: sea-salt and organic enrichment, Atmos. Environ., 44, 670-677, 2010

Watson, J. G., Chow, J.C., and Chen, L.-W. A.: Summary of organic and elemental carbon/black carbon analysis methods and intercomparisons, Aerosol Air Qual. Res., 5, 65-102, 2005.

Weingartner, E., Burtscher, H., and Baltensperger, U.: Hygroscopic properties of carbon and diesel soot particles, Atmos. Environ., 31, 2311-2327, 1997.

Wilson, J., Cuvelier, C., and Raes, F.: A modeling study of global mixed aerosol fields, J. Geophys. Res.-Atmos., 106, 3408134108, 2001.

Wolff, G. T., Ruthkosky, M. S., and Stroup, D. P.: Measurements of $\mathrm{SO}(\mathrm{x}), \mathrm{NO}(\mathrm{x})$ and aerosol species on Bermuda, Atmos. Environ. A-Gen, 20, 1229-1239, 1986.

Wolff, E. W. and Cachier, H.: Concentrations and seasonal cycle of black carbon in aerosol at a coastal Antarctic station, J. Geophys. Res.-Atmos., 103, 11033-11041, 1998.

Yttri, K. E., Aas, W., Bjerke, A., Cape, J. N., Cavalli, F., Ceburnis, D., Dye, C., Emblico, L., Facchini, M. C., Forster, C., Hanssen, J. E., Hansson, H. C., Jennings, S. G., Maenhaut, W., Putaud, J. P., and Tørseth, K.: Elemental and organic carbon in $\mathrm{PM}_{10}$ : a one year measurement campaign within the European Monitoring and Evaluation Programme EMEP, Atmos. Chem. Phys., 7, 5711-5725, 2007,

http://www.atmos-chem-phys.net/7/5711/2007/. 